\title{
Common Garlic (Allium sativum L.) has Potent Anti-Bacillus anthracis Activity
}

Rajinder Kaur ${ }^{1 \#}$, Atul Tiwari" ${ }^{1 \#}$, Manish Manish², Indresh K Maurya ${ }^{1}$, Rakesh Bhatnagar ${ }^{2}$ and Samer Singh ${ }^{1 *}$

\section{Affiliations:}

1. Department of Microbial Biotechnology, Panjab University, Chandigarh-160014, India 2. School of Biotechnology, Jawaharlal Nehru University, New Delhi-110067, India

\footnotetext{
${ }^{\#}$ Authors contributed equally to this work
}

\section{"Corresponding Author:}

Samer Singh, Department of Microbial Biotechnology, Panjab University, Chandigarh-160014, India; Phone: +91-172-2534660; E-mail: samer@pu.ac.in; samersingh@gmail.com

Key Words: Anthrax, Garlic, Traditional medicine, Edible plants, Bacillus anthracis, Allium sativum 


\section{Abstract:}

\section{Ethnopharmacological Relevance:}

A number of common plants found in the Indian subcontinent, e.g., Aegle marmelos (L.) Correa (Bael), Allium cepa L. (Onion), Allium sativum L. (Garlic), Azadirachta indica A. Juss. (Neem), Berberis asiatica Roxb. ex DC. (Daruharidra), Coriandrum sativum L. (Coriander) Curcuma longa L. (Turmeric), Mangifera indica L. (Mango), Morus indica L. (Black mulberry, Shetuta), Ocimum tenuiflorum L. (Ocimum sanctum L., Holy Basil, Tulsi), Ocimum gratissimum L. (Ram Tulsi), Zingiber officinale Roscoe (Ginger), are indicated to have antimicrobial activity and given in diarrhea, dysentery stomachache or as stomachic based upon traditional knowledge and usage profile as per the available literature. They are also given to livestock for their supposed health benefit. Most of the time, they are used for the treatment of different illnesses in spite of the absence of any definitive pieces of evidence for their supposed activity, knowledge about the active principles or their mode of action in pathogens. Anthrax, a disease caused by Bacillus anthracis, remains an important but relatively neglected endemic disease of animals and humans in remote areas of the Indian subcontinent. People in poor endemic areas usually rely on symptom based treatment utilizing parts of different common medicinal plants. Azadirachta indica A. Juss. (Neem) and Curcuma longa L. (Turmeric) have been indicated in literature for anthrax disease based upon traditional use while other plants evaluated in the current study have been indicated for different gastrointestinal conditions.

\section{Aim of the Study:}

Evaluate commonly available edible plants used in the traditional medicine to treat gastrointestinal diseases including those indicated especially for anthrax for potent anti-Bacillus anthracis activity in a form amenable to use in the endemic areas.

\section{Materials and Methods:}

Aqueous extracts made from different plant parts were screened for their anti-Bacillus anthracis activity. The bacteriostatic and bactericidal activities of the extracts were assessed using Agarwell diffusion assays and liquid broth cultures. The bioactive fractions from the most potent antiBacillus anthracis activity displaying Aqueous Garlic Extract (AGE) were isolated by TLC coupled bioautography followed by their characterization using GC-MS. The AGE was assessed for its thermostability and any potential antagonistic interaction with the FDA-approved antibiotics used for anthrax control.

\section{Results:}

Garlic (Allium sativum L.) was identified as the most promising candidate with bactericidal activity against Bacillus anthracis. It consistently inhibited the growth of Bacillus anthracis in agar-well diffusion assay and decreased the viable colony forming units counts in liquid-broth cultures by 6-logs within 6-12 h. GC-MS analysis of the TLC separated bioactive fractions of AGE indicated the presence of previously unreported constituents such as phthalic acid derivatives, acid esters, phenyl group-containing compounds, steroids etc. The AGE displayed acceptable thermostability ( $>80 \%$ anti-Bacillus anthracis activity retained on incubation at $50^{\circ} \mathrm{C}$ 
for $12 \mathrm{~h}$ ) and did not antagonize the activity of FDA-approved antibiotics used for anthrax control.

\section{Conclusion:}

The Aqueous Garlic Extract (AGE) has potent anti-Bacillus anthracis activity better than Azadirachta indica A. Juss. (Neem) and Mangifera indica L. while Curcuma longa L. (Turmeric) does not have any activity in the assays performed. Further work should be undertaken to explore the possible application/use of AGE in preventing anthrax incidences in endemic areas. 


\section{Introduction:}

Anthrax remains one of the major enzootic diseases in many poorer regions of the world, particularly sub-Saharan Africa, Asia, Central and South America (Shadomy et al., 2016; Turnbull, 2008). The causative agent Bacillus anthracis is endemic in this part of the world due to several reasons. Major factors include favorable environmental conditions, availability of a wide range of hosts that includes all hoofed animals (e.g., cattle, horses, sheep, etc.), inadequate surveillance and poor healthcare facilities. There are four types of anthrax based on the route of infection, i.e., cutaneous, gastrointestinal, inhalational and injection-related. The cutaneous or skin anthrax is the most commonly observed form followed by gastrointestinal anthrax in natural settings (Kaur et al., 2013; Turnbull, 2008). Inhalational or pulmonary anthrax is the rarest form and mostly associated with the exposure to large dosage of Bacillus anthracis spores present in air mainly due to bioterror activity (CDC, 2016).

Animals get infected with the pathogen by grazing on contaminated pastures or eating infected carcasses. They frequently develop gastrointestinal and cutaneous forms of anthrax (Shadomy et al., 2016; Turnbull, 2008). Humans also acquire these forms of the anthrax while handling the infected animals, their skins, carcasses or eating the contaminated meat. As expected, the gastrointestinal and cutaneous form of anthrax is most commonly reported in the pastoral population in endemic regions due to their close association with cattle and wild animals. As per a recent estimate about 2000-20,000 human cases may be occurring worldwide per year (Shadomy et al., 2016). However, these estimates could be gross underestimate of the underlying anthrax problem due to the similarity of the symptoms of anthrax infection with common diseases. Gastrointestinal anthrax initially shows the general symptoms of diarrhea, and the inhalational anthrax initially shows the symptoms of flu. Proper management of anthrax is hindered due to the lack of education, absence of surveillance, unavailability of the diagnostic tools and the lack of medical infrastructure that is needed to treat anthrax in fulminant stage (Kaur et al., 2013; Shadomy et al., 2016; Turnbull, 2008).

Bacillus anthracis is one of the most preferred biological warfare agents. Human anthrax has always drawn a lot of attention as it could be resulting from biological warfare or bioterror activity. In modern times, anthrax has gained a lot of notoriety due to 'The Sverdlovsk anthrax outbreak of 1979' that possibly resulted from the leakage of spores from a military facility and the well highlighted anthrax spore attacks in USA through postal service in the year 2001 after September 11 terrorist attacks (Kaur et al., 2013). A lot has been done to prevent, diagnose and treat anthrax in a timely manner (CDC, 2016; Kaur et al., 2013; Turnbull et al.1999). Vaccines are available for human as well as veterinary use (Kaur et al., 2013; Shadomy et al., 2016; Turnbull, 2008). Diagnostic kits are available to detect the possible exposure to Bacillus anthracis. Various antibiotics are available to treat the possible Bacillus anthracis infection as it is sensitive to number of antibiotics such as penicillin, ciprofloxacin etc. (CDC, 2016; FDA, 2016). As per the recent guidelines published by 'Centers for Disease Control' and 'Anthrax prevention expert panel', extended combination antibiotic treatment with three or more antibiotics is recommended for the treatment of suspected exposure to anthrax spores due to the inability of antibiotics to kill spores and the observed delay in germination of the spores in 
experimental host animals (CDC, 2016; Hendricks et al., 2014). Prophylactic antibiotic therapy for 60 days is recommended for the treatment of the inhalational anthrax in conjunction with available anthrax vaccines (CDC, 2016; FDA, 2016; Weiss et al., 2015). However, to treat the fulminant stage anthrax, when toxemia and bacteremia have appeared, the ability to treat patients is less than satisfactory in most parts of the world. It is primarily due to the way the pathogenesis of anthrax by Bacillus anthracis works. Once the toxins produced by Bacillus anthracis, i.e., Lethal toxin (LeTx) and Edema Toxin (EdTx) have reached a critical threshold level in the body, use of antibiotics to treat the disease is ineffective as antibiotics cannot not inhibit the action of toxins. It may lead to sudden death of infected animal or human being (Shadomy et al., 2016; Turnbull, 2008). In the absence of sufficient medical support in anthrax endemic regions of Asia and Africa, people still use and rely on traditional medicine. Traditional medicine is based on use of various plants or animal products to treat different ailments both in humans as well as animals. This system of medicine is based on empirical evidence and the traditional knowledge of symptomatic treatment gathered over thousands of years to treat such diseases. The symptoms of anthrax are so similar to other less serious diseases that in the absence of appropriate diagnostic tests there is always a high probability of getting wrong diagnosis or treatment.

The identification of anti-Bacillus anthracis activity in commonly available edible plants or plant parts could be a big help in fighting the endemic anthrax in poorer parts of the world. The conscious evidence based inclusion of such plant(s) or the plant part(s) in the regular diet could effectively decrease the anthrax incidences. They may also be employed in decontaminating the supposed contaminated sites. With this aim in mind, the current study had been undertaken to evaluate and characterize various commonly available edible plants which are used as food items as well as traditional medicine for antimicrobial activity and given in diarrhea, dysentery stomachache or as stomachic (See Table S1 Traditional use of plants as indicated in literature for details and references), for their ability to kill Bacillus anthracis. We evaluated a number of edible plants commonly available in Indian subcontinent which are indicated for different ailments and also purported to have antimicrobial or stomachic properties with regard to gastrointestinal discomfort or disturbances, i.e., Aegle marmelos (L.) Correa (Bael), Allium cepa L. (Onion), Allium sativum L. (Garlic), Azadirachta indica A. Juss. (Neem), Berberis asiatica Roxb. ex DC. (Daruharidra), Coriandrum sativum L. (Coriander) Curcuma longa L. (Turmeric), Cynodon dactylon (L.) Pers (Bermuda grass), Mangifera indica L. (Mango), Morus indica L. (Shetut), Ocimum tenuiflorum L. (Ocimum sanctum L.) (Holy Basil, Tulsi), Ocimum gratissimum L. (Ram Tulsi), Zingiber officinale Roscoe (Ginger), Psidium guajava L. (Guava), (Duke et al., 2002; U.S. Department of Agriculture, 1992-2016). Although Azadirachta indica A. Juss. (Neem), Allium cepa L. (Onion), and Curcuma longa L. (Turmeric) have been indicated in traditional/folk medicine for treating anthrax like symptoms in humans and animals their characterization and validation had been lacking(Duke et al., 2002, 2008; U.S. Department of Agriculture, 1992-2016). During the course of our study a study by Elisha et al. 2016 had also appeared that evaluated the acetone extracts of 9 medicinal plants from South Africa against Bacillus anthracis Sterne strain (Elisha et al., 2016). The acetone extracts from plants Maesa lanceolata, Bolusanthus speciosus, Hypericum roeperianum, Morus mesozygia and Pittosporum viridiflorum displayed good anti-Bacillus anthracis activity but variable cytotoxicity to vertebrate 
cells. In our endeavor to identify commonly used edible plants that may be used as anti-Bacillus anthracis agent in the poorer and remote regions, we tried to identify plants with sufficiently high concentration of water soluble/extractable anti-Bacillus anthracis constituents so that it would not require any complex organic phase extraction for its effective application in the field. In our study, Bacillus anthracis Sterne strain - a pXO1 virulence plasmid harboring but pXO2 virulence plasmid lacking attenuated stain that is also used in the veterinary anthrax vaccine, was used as a surrogate for assessing the effect of various plant extracts on the wild type pathogenic Bacillus anthracis strains. A number of plants such as Allium sativum L. (Garlic), Azadiracta indica A. Juss. (Neem), Mangifera indica L. (Mango), Berberis asiatica Roxb. ex DC. (Daruharidra), Psidium guajava L.(Guava) and Allium cepa L. (Onion) displayed varying level of anti-Bacillus anthracis activity in our study that differed from batch to batch. Azadiracta indica A. Juss. (Neem) and Allium cepa L. (Onion) had been indicated for anthrax in Dr. Duke's Phytochemical and Ethnobotanical Databases (U.S. Department of Agriculture, 1992-2016) and Duke's handbook of medicinal plants of the Bible (Duke et al., 2008). Allium sativum L. (Garlic), a common spice and herb used in food appeared to contain the highest concentration of antimicrobial activity among the tested plants in our comparative analysis of the aqueous extracts. The Aqueous Garlic Extract (AGE) exposure changed the morphology of Bacillus anthracis cells within $3 \mathrm{~h}$ and decreased the number of viable cells in the liquid growth medium by 6 logs within 6-12 h. Preliminary characterization of the bioactive principles present in AGE which may be responsible for its anti-Bacillus anthracis activity, indicated it to be different from the ones already ascribed in the literature for the general antibacterial activity of Garlic (Duke et al., 2002; Goncagul and Ayaz, 2010; Sharifi-Rad et al., 2016; U.S. Department of Agriculture, 1992-2016). Furthermore, the AGE did not seem to antagonize the activity of antibiotics approved by Food and Drug Administration, USA (FDA) for the anthrax control suggesting its safer interaction with the antibiotics.

\section{Material and Methods}

\subsection{Bacterial strains and Chemicals:}

The commonly used laboratory strain Escherichia coli DH5a and Bacillus anthracis Sterne 34F2 - an avirulent ( $\mathrm{pXO1}{ }^{+}, \mathrm{pXO2}$ ) vaccine strain were used in the current study. All bacterial growth media such as Muller-Hinton Broth (MHB), Muller-Hinton Agar (MHA), Luria Broth (LB), Luria Agar (LA), Nutrient Agar (NA), Nutrient Broth (NB) and other media components were purchased from HiMedia Laboratories Ltd (India). The antibiotics and other routine chemicals were from Sigma Aldrich Inc (St. Louis, MO, USA). The organic solvents used were from Merck Millipore (Merck Life Science Private Limited, India).

\subsection{Collection of plant samples:}

The dried cloves/bulbs of Garlic (Allium sativum L.) and Onion (Allium cepa L.), and the dried uncrushed rhizomes of turmeric (Curcuma longa L.) were purchased from the local market of Chandigarh, India. In case of other plants, the fresh leaves from the identified plants from the Panjab University, Chandigarh, India premises were collected in sterile polythene bags on the day of experimentation and immediately transported back to the laboratory for use. The voucher 
specimens of Garlic (Allium sativum L.) were deposited in the herbarium of the Panjab University, Chandigarh (PAN) with Acc. No. 21146, 21147 and 21148 . The Garlic batch with Acc. No. 21146 was used for all the experiments described in the current study including where it was compared (referred as sample No. 1) with other batches of Garlic (Acc. No. 21147 and 21148 referred as sample No. 2 and 3, respectively) for the presence of water extractable antiBacillus anthracis activity.

\subsection{Preparation of the aqueous plant extract:}

Two grams of freshly plucked leaves, bulbs or rhizomes were surface sterilized by $70 \%$ ethanol (except turmeric, which was used as such) followed by drying for 15 minutes at room temperature under aseptic conditions. To get the aqueous extract, the samples were put individually in sterile mortar, $5 \mathrm{ml}$ of sterile ultrapure water was added, and the sample was crushed using a sterile pestle followed by separating out the insoluble portion by passing the suspension through a sterile Whatman No. 1 filter paper. The soluble filtered aqueous extracts of plants were kept at $4^{0} \mathrm{C}$ until use (usually within 2-4 h) unless noted otherwise.

\subsection{Anti-Bacillus anthracis activity assessment of aqueous plant extracts:}

2.4.1 Agar-well diffusion assay: The overnight grown Bacillus anthracis Sterne strain culture was used to re-inoculate the fresh Muller-Hinton Broth (MHB) medium and the culture was allowed to reach the optical density at $600 \mathrm{~nm}\left(\mathrm{OD}_{600}\right)$ of $0.3-0.4$. This culture was harvested, diluted in fresh medium to adjust its $\mathrm{OD}_{600}$ to 0.1 then further diluted so as to get evenly distributed lawn of the cells when $50-100 \mu \mathrm{l}$ of diluted culture is spread on the Muller-Hinton Agar (MHA) plate or a mat when mixed with molten $1 \% \mathrm{MHA}$ and incubated at $37^{\circ} \mathrm{C}$ for $12-16 \mathrm{~h}$. The test wells in the agar plate were made by punching holes using the wide mouth of a $200 \mu l$ pipette tips.

For estimating and comparing the growth inhibitory potential of different plant extracts fixed volume of the plant extracts were loaded in the different wells of the same MHA plate. The antibiotic Rifampicin (2-8 $\mu \mathrm{g}$ ) was used as a positive control for growth inhibition (+ Ctrl) while ultrapure water that was employed as a solvent/diluent for the extracts was used as a negative control for growth inhibition (- Ctrl) in the assay. The plates were incubated for $12-72 \mathrm{~h}$ at $37^{\circ} \mathrm{C}$ and the zones of inhibition (ZOI) were estimated at different time intervals.

The loss of anti-Bacillus anthracis activity of Aqueous Garlic Extract (AGE) on incubation at different temperatures, both above and below the room temperature, was evaluated by incubating the $200 \mu \mathrm{l}$ aliquots of $\mathrm{AGE}$ at $4^{\circ} \mathrm{C}$ to $100^{\circ} \mathrm{C}$ for $0 \mathrm{~h}$ to 15 days, followed by residual activity assessment by agar-well diffusion assay as described above. The observed zone of inhibition (ZOI) was used as a measure of remaining/residual anti-Bacillus anthracis activity. The relative zone of inhibition (\%) was calculated as equal to '(Observed ZOI for sample incubated at test temperature $\left({ }^{\circ} \mathrm{C}\right)$ / Observed $\mathrm{ZOI}$ for given sample incubated at $4^{\circ} \mathrm{C}$ temperature $)^{\star} 100$.

2.4.2 Growth assay: The overnight grown culture of Bacillus anthracis Sterne strain was reinoculated in MHB medium, incubated for $1.5-2 \mathrm{~h}$ at $37^{\circ} \mathrm{C}$ with agitation (150 rpm) to allow it to 
reach $\mathrm{OD}_{600}$ of about 0.4 , then diluted with $\mathrm{MHB}$ medium to adjust its $\mathrm{OD}_{600}$ to 0.100 . Different volumes $(0-500 \mu \mathrm{l})$ of aqueous extract of Garlic (Allium sativum L.) or AGE $(40 \% \mathrm{w} / \mathrm{v})$ were added to the $5 \mathrm{ml}$ of the diluted broth cultures $(\sim 0-36 \mathrm{mg} / \mathrm{ml})$, followed by incubation at $37^{0} \mathrm{C}$. The change in the optical density, i.e., $\mathrm{OD}_{600}$ at regular time intervals $(0-24 \mathrm{~h})$ was monitored to assess the effect of the extract on the growth of Bacillus anthracis.

\subsection{Sample storage and verification/identification (DNA barcoding):}

DNA from the Garlic (Allium sativum L.) sample (voucher deposited in the herbarium of the Panjab University, Chandigarh (PAN) with Acc. No. 21146) was extracted using Plant DNA isolation kit (Hi-Media). The conserved region of the rbcL gene was PCR amplified using the forward primer 5' TGTAAAACGACGGCCAGTATGTCACCACAAACAGAGACTAAAGC 3' and the reverse primer 5' CAGGAAACAGCTATGACGTAAAATCAAGTCCACCACG 3'. The program used was 1 min of initial denaturation at $94^{\circ} \mathrm{C}$; 30 cycles of 45 seconds of denaturation at $94^{\circ} \mathrm{C}$, $30 \mathrm{sec}$ of annealing at $60^{\circ} \mathrm{C}, 1 \mathrm{~min} 30 \mathrm{sec}$ of extension at $72^{\circ} \mathrm{C}$; followed by a final extension of $10 \mathrm{~min}$ at $72^{\circ} \mathrm{C}$. The amplified product was purified and sequenced on commercially available Sanger sequencing platform. The sequence of the rbcL gene fragment was aligned with reference sequences using nucleotide blast available at https://blast.ncbi.nlm.nih.gov/Blast.cgi?PROGRAM=blastn\&PAGE_TYPE=BlastSearch\&BLAST _ SPEC=\&LINK_LOC=blasttab\&LAST_PAGE=blastn.

\subsection{Morphological characterization of Aqueous Garlic Extract (AGE) exposed Bacillus anthracis cells by Scanning Electron Microscopy:}

The exponentially growing Bacillus anthracis cells were exposed to AGE for 0,3 and $8 \mathrm{~h}$ followed by processing for observation by scanning electron microscope. Briefly, the Bacillus anthracis cells were fixed with $2 \%$ glutaraldehyde for $1 \mathrm{hr}$ at room temperature, washed with phosphate buffer (100mM, pH 7.2), incubated with Osmium tetroxide for $1 \mathrm{~h}$, dehydrated by serial passage in 10, 30, 50, 75, 90, and 100\% ethanol and finally sputter coated with gold. The images were taken at different magnification using JSM 6100 (JEOL) Scanning Electron Microscope (SAIF, CIL, DST-supported facility at Panjab University, Chandigarh).

\subsection{Evaluations of the ability of Aqueous Garlic Extract (AGE) to kill Bacillus anthracis cells:}

2.7.1 Time-Kill Assay: The exponentially growing Bacillus anthracis culture $\left(\mathrm{OD}_{600} \sim 0.4\right)$ was centrifuged at $10,000 \mathrm{~g}$ for 5 minutes to pellet down the cells. The pelleted cells were washed with saline or MHB medium, followed by resuspension in the normal saline or MHB medium so as to have approximately $10^{6}$ colony forming units (CFU) $/ \mathrm{ml}$. It was supplemented with AGE at a final concentration of 0 to $3.6 \% \mathrm{w} / \mathrm{v}$ and incubated at $37^{\circ} \mathrm{C}$ for $0-24 \mathrm{~h}$ with shaking (150rpm), followed by plating of the AGE exposed Bacillus anthracis culture on MHA ( $2 \%$ agar) medium plates and incubation of the plates at $37^{\circ} \mathrm{C}$ for $15-18 \mathrm{~h}$. The colonies obtained were counted and the remaining $\mathrm{CFU} / \mathrm{ml}$ in the AGE supplemented $\mathrm{MHB}$ medium or saline suspension was calculated for different AGE exposure durations (0-12 hrs).

2.7.2 Interaction of Aqueous Garlic Extract (AGE) with antibiotics used for Anthrax treatment: The AGE was evaluated for its relative potency and possible antagonistic interaction 
with the commonly employed antibiotics used to treat anthrax, i.e., Amoxicillin (Am), Cefixime $(\mathrm{Ce})$, Ciprofloxacin (C), Doxycycline (Dox), Levofloxacin (L), Penicillin (P), Rifampicin(R), Sulfamethoxazole (S), Tetracycline(T) using agar well diffusion assay as described above in section 2.4.1. The antibiotics Ciprofloxacin, Doxycycline, Levofloxacin and Penicillin are approved by FDA for anthrax treatment (FDA, 2016) while Sulfamethoxazole, a Folic acid biosynthesis inhibitor, known to be ineffective against Bacillus anthracis (Weiss et al., 2015) was used as a negative control. The ZOI remaining after different durations of incubation at $37^{\circ} \mathrm{C}$ were noted. The shape of ZOI was also ascertained to assess the interaction between AGE and different antibiotics.

2.7.3 Minimum Inhibitory concentration (MIC) determination \& fractional inhibitory concentration index (FICI) assessment: The checkerboard broth dilution method was used to determine the Minimum Inhibitory Concentration (MIC) of AGE as well as the combined effect of AGE and different antibiotics (i.e., synergistic, no effect, antagonistic as fractional inhibitory concentration index) on $B$. anthracis Sterne strain. Briefly, the $B$. anthracis cells grown overnight in Mueller Hinton Broth (MHB) were inoculated in fresh MHB $(100 \mu$ l of culture in $5 \mathrm{ml} \mathrm{MHB})$ followed by incubation at $37^{\circ} \mathrm{C}$ with $150 \mathrm{rpm}$ till the $\mathrm{OD}_{600}$ reaches 0.4 (90-120 minutes). It was diluted in fresh $\mathrm{MHB}$ to adjust $\mathrm{OD}_{600}$ to 0.2 or 0.1 . A $100 \mu \mathrm{l}$ aliquot was inoculated in 96 well plate already supplemented with different concentrations of antibiotic and AGE in 100 $\mu$ MHB in each well followed by overnight incubation at $37^{\circ} \mathrm{C}$ with agitation at $150 \mathrm{rpm}$. Different controls such as media control, i.e., only MHB, no treatment or bacterial cell control, i.e., cells in media, AGE control, i.e., AGE alone in media, antibiotic control, i.e., antibiotic in media were also included/set for experiments as applicable. The OD of wells was taken at $620 \mathrm{~nm}$ using ELISA plate reader to assess the bacterial growth in different wells. To confirm the viability of cells MTT assay was also performed where the formation of blue/purple color crystal (formazan) indicates the presence of viable cells whereas no blue color appearance indicates the dead cells (Singh et al., 2002). The viability of culture was also confirmed by platting the culture on MHA plate from wells with no observable increase in OD growth of $B$. anthracis. The synergistic, antagonist or indifferent interaction of AGE with antibiotics approved by FDA for anthrax treatment was determined by calculating fractional inhibitory concentration index (FICl) using the following formula: $\sum \mathrm{FICl}=\mathrm{FIC}(\mathrm{A})+\mathrm{FIC}(\mathrm{B})$, where, $\mathrm{FIC}(\mathrm{A})=\mathrm{MIC}(\mathrm{A})$ in combination $/ \mathrm{MIC}(\mathrm{A})$ alone; and $\mathrm{FIC}(\mathrm{B})=\mathrm{MIC}(\mathrm{B})$ in combination/ $\mathrm{MIC}(\mathrm{B})$ alone. The interaction was categorized as follows: strongly synergistic effect, $\mathrm{FIC}<0.5$; synergistic effect, $\mathrm{FIC}<1$; additive effect, $\mathrm{FIC}=1$; no effect, $1<\mathrm{FIC}<2$; antagonistic effect, FIC $>2$ (Mor et al., 2015).

\subsection{Plasmid loss assay:}

To assess the possibility of AGE induced curing or loss of pXO1 plasmid, the Bacillus anthracis cells were grown in the presence of different concentration of AGE $(0-3.6 \% \mathrm{w} / \mathrm{v})$ that retarded/delayed or inhibited the growth of Bacillus anthracis cells in the broth culture. The cultures exposed to different concentrations of AGE were plated on MHA plates and the colonies that developed on incubation at $37^{\circ} \mathrm{C}$ for $12-16 \mathrm{~h}$ were examined for the loss of $\mathrm{pXO} 1$ by assessing the presence of $\mathrm{PXO1}$ encoded toxin gene pagA (encodes for Protective Antigen or PA) by colony PCR. The primer set used for $\mathrm{pXO1}$ borne gene pagA amplification included a forward primer PA-1588F 5'GCA TTT GGA TTT AAC GAA CCG A 3' and a reverse primer PA2016R 5'TCC ATC TTG CCG TAA ACT AGA A 3', and that for the chromosomal gene phoP 
amplification included a forward primer PhoP-F 5'GCG CCC ATG GGC ATG AAC AAT CG 3' and a reverse primer PhoP-R 5'GCG CCT CGA GTT CAT CCC CTT TTG GC 3'. The PCR condition used for the colony PCR was 30 cycles of ' $45 \mathrm{sec}$ of denaturation at $94^{\circ} \mathrm{C}, 30 \mathrm{sec}$ of annealing at $58^{\circ} \mathrm{C}$ for pagA $60^{\circ} \mathrm{C}$ for phoP, $1 \mathrm{~min} 30 \mathrm{sec}$ of extension at $72^{\circ} \mathrm{C}$, followed by 10 min of final extension at $72^{\circ} \mathrm{C}$.

\subsection{Thin Layer Chromatography (TLC), TLC - Bioautography and Mass Spectrometry:}

A 5-10 $\mu \mathrm{l}$ aliquot of the filtered Aqueous Garlic Extract (AGE) was applied $1 \mathrm{~cm}$ away from the base of silica gel 60 TLC plate (Merck Millipore). The applied sample was air dried for $10 \mathrm{~min}$ at $37^{\circ} \mathrm{C}$, followed by developing the chromatogram with Toluene-Acetone (7:3) mixture as the developing solvent system. The chromatograms were run in duplicate. The developed chromatograms were air dried by keeping them at $37^{\circ} \mathrm{C}$ for $20 \mathrm{~min}$ so that the solvents get completely evaporated from the chromatograms. The chromatograms were observed under short- and long- UV radiation. One set of chromatogram was used for bioautography to test the ability of fractionated components to inhibit the growth of Bacillus anthracis and the other set was used as the reference chromatogram - that was later used for mass spectrometry to identify the bioactive principles with anti-Bacillus anthracis activity. The positions of UV-fluorescent bands on chromatogram were marked. For bioautography, the developed chromatograms were placed in petri-plates then the molten 1\% MHA medium mixed with exponentially growing Bacillus anthracis cells was poured over them, followed by incubation at $37^{\circ} \mathrm{C}$ for $15-18 \mathrm{~h}$. The presence/location of the zone of growth inhibition on the chromatograms was noted. For mass spectrometry the areas corresponding to the zone of inhibition and encompassing the UVfluorescent bands were scratched from the duplicate chromatogram with the help of sterile blades, placed in separate $1.5 \mathrm{ml}$ tubes containing $100 \mu \mathrm{l}$ of absolute ethanol and then processed for Gas chromatography - Mass spectrometry (GC-MS) analysis. As a control for the process the butanolic Garlic extract was also prepared and processed for GC-MS analysis. The samples were analyzed using Thermo Scientific Gas Chromatograph - Mass Spectrometer or GC-MS (Thermo Trace 1300 GC and MS Thermo TSQ 8000) fitted with column TG 5MS (30m $X 0.25 \mathrm{~mm}, 0.25 \mu \mathrm{m})$ that employed NIST 2.0 Library to identify potential compound hits.

\section{Results:}

\subsection{A number of common plants have anti-Bacillus anthracis activity:}

The aqueous extracts from different plants were analyzed for their ability to prevent the growth of Bacillus anthracis cells using agar well diffusion assay (Figure 1A-B). The growth inhibition potential assessment of the aqueous extracts from edible plants from one representative evaluation experiment is presented in Table 1. Among the tested plants, Garlic (Allium sativum L.) that generally forms part of a regular human diet, was found to be the most potent in terms of its anti-Bacillus anthracis activity content when compared on wet weight basis (Figure 1A-B, Table 1). The aqueous extract of Garlic produced a zone of growth inhibition (ZOI) measuring about $18 \mathrm{~mm}$ upto $72 \mathrm{hr}$ of incubation similar to the positive control Rifampicin $(8 \mu \mathrm{g})$ while those produced by others such as Neem (Azadirachta indica A. Juss.) and Mango (Mangifera indica L.) were comparatively smaller measuring just about $10-11 \mathrm{~mm}$ after $12-24$ hours of incubation that too disappeared by $72 \mathrm{~h}$ of incubation. The extracts from Daruharidra (Berberis asiatica Roxb. ex DC), Onion (Allium cepa L.) and Guava (Psidium guajava L.) did not produce a ZOI in 
the shown agar-well diffusion assay when $50 \mu \mathrm{l}$ of the $40 \% \mathrm{w} / \mathrm{v}$ aqueous extract was evaluated (Figure 1A-B, Table 1). However, based upon multiple activity evaluation experiments, it may be concluded that the activity in extracts of Neem, Mango, Daruharidra, Onion, and Guava are variable (batch to batch, plant to plant, and time to time) and on an average the anti-Bacillus anthracis activity content in the aqueous extracts made from different plants would be in the order Garlic (Allium sativum L.) >> Neem (Azadirachta indica A. Juss.), Mango (Mangifera indica L.)> Daruharidra (Berberis asiatica Roxb. ex DC), Onion (Allium cepa L.), Guava (Psidium guajava). The aqueous extract from rhizome of Curcuma longa L. did not display any antiBacillus anthracis activity in any of the agar well diffusion assay. As the Garlic extract showed minimum variability from experiment to experiment and batch to batch, it was chosen for further characterization.

\subsection{Aqueous Garlic (Allium sativum L.) Extract (AGE) inhibits growth of Bacillus anthracis in a dose dependent manner:}

We evaluated the ability of AGE in inhibiting the growth of exponentially growing Bacillus anthracis in MHB medium. The supplementation of MHB medium with different quantities of AGE $(0-3.6 \% \mathrm{w} / \mathrm{v})$ inhibited the growth of exponentially growing Bacillus anthracis culture in a dose dependent manner (Figure 1C). The supplementation of MHB at concentrations $\geq 1.9 \% \mathrm{w} / \mathrm{v}$ of AGE completely inhibited growth of Bacillus anthracis while lower concentrations retarded/delayed the growth in a dose dependent manner. The corresponding MIC for Bacillus anthracis $\leq 20 \mathrm{mg} / \mathrm{ml}$ was lower than that reported for Gram-positive bacterial strains reported previously, i.e., range $142.7-35.7 \mathrm{mg} / \mathrm{ml}$, but fell in the MIC range of $35.7-1.1 \mathrm{mg} / \mathrm{ml}$ reported for Gram-negative strains in Duke's handbook of medicinal plants of the Bible (Duke et al., 2008) and references therein indicating more sensitive nature of Bacillus anthracis as observed for its relatively sensitive nature to different antimicrobials.

\subsection{AGE induces morphological changes in Bacillus anthracis:}

To assess the possible mechanism of anti-Bacillus anthracis activity the morphology of Bacillus anthracis cells growing in cultures supplemented with $0 \% \mathrm{w} / \mathrm{v}$ AGE (control) and $1.9 \% \mathrm{w} / \mathrm{v}$ AGE (treated) for different durations were examined using light microscopy and scanning electron microscopy. The control Bacillus anthracis culture which was not exposed to AGE displayed presence of cells in long chains as expected (Fig. 2 A top part, control cells, and see also Fig. 1D) while the culture exposed to $1.9 \% \mathrm{w} / \mathrm{v}$ AGE, a growth inhibitory concentration, showed appearance of cells in relatively shorter chains and as single cells (Fig. 2A bottom part, treated cells) within 3 hours of incubation, indicating potential disruption/dissolution or weakening of the cell walls by AGE. Incubation for $8 \mathrm{~h}$ resulted in the appearance of debris (data not shown).

\subsection{AGE is bactericidal to vegetative Bacillus anthracis cells:}

The bactericidal activity of AGE was assessed by exposing Bacillus anthracis cells in the log phase of growth with different concentration of AGE in the presence of growth medium or saline followed by estimating the number of surviving colony forming units $/ \mathrm{ml}$ (i.e., CFU/ml) after different time intervals $(0-12 \mathrm{~h})$. The AGE at concentration $1.9 \% \mathrm{w} / \mathrm{v}$ and above was found to cause decrease in the viability (CFU) of vegetative Bacillus anthracis cells by as much as 6 logs (Fig. 2B and C) within 6-12 h. However, $1 \% \mathrm{w} / \mathrm{v}$ AGE which could only retard the growth in the 
presence of MHB medium (See Fig 1C; data not shown in Fig 2B) was found to kill Bacillus anthracis cells in the absence of MHB (Fig. 2C) indicating increased efficacy of AGE in killing Bacillus anthracis cells in the absence of growth medium components.

\subsection{AGE does not induce virulence plasmid pXO1 loss from Bacillus anthracis Sterne strain:}

The colonies that developed on MHA plate on inoculation of Bacillus anthracis culture exposed to sub-inhibitory concentration of AGE (1\% w/v) for different durations $(0-24 \mathrm{~h})$, were examined for the presence of pagA gene - a virulence plasmid pXO1-borne gene, and phoP gene - a chromosome-borne gene using polymerase chain reaction (Figure 3 ). The exposure to subinhibitory concentration of AGE for $24 \mathrm{~h}$ did not cause the loss of $\mathrm{pXO1}$ plasmid as apparent from the specific amplification of the plasmid borne pagA gene in $100 \%$ of the random colonies (8 out of 8) screened (Fig. 3 A). The sampled colonies formed by the culture of Bacillus anthracis cells exposed to $1 \% \mathrm{w} / \mathrm{v}$ AGE for different durations, i.e., 0 - $24 \mathrm{~h}$ also consistently tested positive for the presence of pagA gene indicating retention of $\mathrm{pXO1}$ plasmid and the inability of $A G E$ to induce virulence plasmid pXO1 loss or curing (Fig. $3 \mathrm{~B}$ ). Similar results were obtained with colonies formed from residual surviving cells present in the Bacillus anthracis culture exposed to growth inhibitory concentration of AGE, i.e., $>1.9 \% \mathrm{w} / \mathrm{v}$ for shorter durations (1 - $3 \mathrm{~h}$; data not shown).

\subsection{Autobiography of AGE and Mass spectrometry of bioactive component:}

To characterize the bioactive constituents in AGE, the conditions for its separation into bioactive entities were performed by coupling the analytical TLC separation of AGE (Supplementary Figure 1A) with bioautography (Sup. Figure 1B) followed by elution of the potential bioactive components from the corresponding place on the duplicate TLC chromatogram of AGE that was developed in parallel and subjecting the eluted fractions to GC-MS for detection of the ions that may indicate the identity of bioactive compound (Figure Sup. Figure 2). Among the tested solvent systems, the solvent system comprising of Toluene-Acetone (7:3) that performed best in separating two UV - fluorescent spots/components in AGE on silica TLC (Sup. Figure 1A, compare chromatogram No. 3 of bottom panel with others) was used to fractionate AGE on silica TLC followed by bioautography of the same (Sup. Figure 1B). The ability to inhibit Bacillus anthracis growth was found to correspond with positions of UV-fluorescent spots (Sup. Figure 1B; encircled in white in right panel: AGE TLC plate). The silica around and including UVfluorescent spots observed in the AGE fractions that corresponded to anti-Bacillus anthracis activity (growth inhibition) on bioautography were labeled G1 and G2 (Sup. Figure 2A), isolated and processed for GC-MS analysis. The GC-MS profile of G1 and G2 are shown as Sup. Figure 2B and the partial list of potential compound hits as ascertained using the NIST 2.0 library are provided in Table 2 while the complete list can be found in the supplementary information (Sup. Figure 3 and 4). GC-MS analysis was done to ascertain the presence of compounds which are already reported to be responsible for the antimicrobial activity of Garlic against various pathogenic bacteria (Duke et al., 2002; Goncagul and Ayaz, 2010; Rana et al., 2011; SharifiRad et al., 2016; U.S. Department of Agriculture, 1992-2016). Surprisingly, the ions generated did not seem to indicate the presence of the well-known bioactive organosulfur compounds in Garlic, e.g., alliin, S-allyl-L-cysteine, y-glutamyl-S-allyl-L-cysteine, and allicin etc. though other 
class of compounds with potential antimicrobial activity, e.g., phthalic acid derivatives, acid esters, phenyl group containing compounds, steroids were identified (Table 2, Sup. Figure 3 and Sup. Figure 4). We speculated the absence of the well-known antibacterial compounds in our bioactive fraction to be the result of previously unidentified constituents or our use of water as extractant and the methodology adopted that would have led to the reduced extraction, decomposition and/or loss of the previously reported bioactive compounds. GC-MS analysis of the butanolic extract of Garlic was performed to assess the validity of this speculation. The butanolic extract indeed contained well known allyl derivatives as well as multiple S-containing compounds (Sup. Figure 5) supporting the speculation.

The identity of the vouchered Garlic sample was also verified by sequencing of the rbcL gene fragment amplified from the Garlic sample DNA. The sequence of the amplified rbcL gene fragment displayed more than $99 \%$ identity to the gene bank deposited $r b c L$ gene sequences of Allium sativum L. (submitted to GenBank MH020774), confirming the authenticity of the Garlic sample.

\subsection{Anti-Bacillus anthracis activity of AGE is stable near room temperature:}

The ability of the anti-Bacillus anthracis activity of AGE to tolerate different temperatures was evaluated to assess its potential field use. Based upon the ZOI produced by AGE samples incubated at different temperatures $\left(0-100^{\circ} \mathrm{C}\right)$ for different durations $(0-15$ days), it can be inferred that the anti-Bacillus anthracis activity of AGE is quite stable around room temperature $\left(20-30^{\circ} \mathrm{C}\right)$, and also moderately stable at temperatures encountered near tropics during the summer season (see Figure $4 \mathrm{~A}$ and $4 \mathrm{~B}$ ). It retained more than $80 \%$ of anti-Bacillus anthracis activity on incubation at $40^{\circ} \mathrm{C}$ and $50^{\circ} \mathrm{C}$ for $>1$ day and $12 \mathrm{~h}$, respectively. At $4^{\circ} \mathrm{C}$ incubation temperature, AGE did not show any loss in activity upto 15 days. However, on incubation at $100^{\circ} \mathrm{C}$ temperature the anti-Bacillus anthracis activity of AGE was lost in about 10 minutes (data not shown); suggesting at least S-allylcysteine (Kodera et al., 2002) which is reportedly quite stable at $100^{\circ} \mathrm{C}$ would not be the bioactive constituent responsible for the anti-Bacillus anthracis activity shown by AGE.

\subsection{Different batches of Garlic show similar anti-Bacillus anthracis activity:}

The bioactive content of plant products are known to vary with origin, age and time, so for using any plant product for any particular purpose the plant or plant products from different origin or of age must consistently display desired characteristics within acceptable limits. To this end we evaluated garlic samples collected/bought from local market over a period of time (April 2016 to December 2016) for anti- Bacillus anthracis activity using agar-well diffusion assay. All the three samples evaluated displayed robust and similar anti-Bacillus anthracis activity as apparent from the production of 21-23 mm size ZOls (Figure 4C and 4D).

\subsection{AGE does not antagonize the activity of antibiotics recommended for the treatment of possible Bacillus anthracis exposure:}

To evaluate if AGE may affect the action of antibiotics prescribed for anthrax treatment, Amoxicillin (Am), Cefixime (Ce), Ciprofloxacin (C), Doxycycline (Dox), Levofloxacin (L), Penicillin (P), Rifampicin (R), Tetracycline (T), (CDC, 2016; FDA, 2016) were assayed for 
possible interaction using agar well diffusion assay, as done before. All the antibiotics which are currently in use for anthrax treatment inhibited the growth of Bacillus anthracis as expected (Figure. 5A and 5B and Sup. Fig 6). The AGE did not appear to antagonize the activity of antibiotics used in the anthrax control (FDA, 2016) as summarized in Figure 4F, rather it appeared that the AGE may be potentially showing synergy with antibiotics. Further experimentation to estimate the MIC value along with fractional inhibitory concentration index (FICl) estimation indicated the antibiotic Penicillin, Rifampicin, Tetracycline act synergistically while the antibiotic Amoxicillin, Cefixime, Ciprofloxacin, Doxycycline, Levofloxacin appeared to be indifferent when combined with AGE, in inhibiting/killing the Bacillus anthracis cells (Fig 5C and Fig 5D). These observations suggest that Garlic in the form of AGE could be one of the readily available natural anti-Bacillus anthracis agents, though largely unexplored, that can be potentially employed as preventive as well as therapeutic agent after further characterization.

\section{Discussion and Conclusion:}

Anthrax remains a disease of greater concern in poorer parts of the world that also have larger share of livestock but relatively poor veterinary healthcare infrastructure such as in Indian subcontinent and Africa (Shadomy et al., 2016; Turnbull, 2008). Its reemergence in the areas which were earlier declared anthrax free is also on rise as recently observed in parts of Russia and Africa (Shadomy et al., 2016). A better improved management and prevention strategy needs to be put in place before it is too late. In Indian context, as per the epidemiological data from 1991 to 2010 collated by National Animal Disease Referral Expert System (NADRES), India, it remains one of the top ten killer diseases of the livestock (Rahman, 2012). The condition in other regions of Indian subcontinent could be similar. Mostly the livestock in poorer remote regions bear the brunt of anthrax infection (Shadomy et al., 2016; Turnbull, 2008). Though antibiotics and vaccines would remain the mainstay of controlling anthrax in immediate future, their availability and reach in poorer regions may remain limited. The issue of antibiotic resistance may also arise sooner or later in Bacillus anthracis as being observed in other more common pathogens. In this direction, the discovery of new antimicrobials (Blaskovich et al., 2017) or agents that may affect the pathogenicity of organisms by modulating the quorum sensing (Bhardwaj et al., 2013; Ta and Arnason, 2015) or cause loss of virulence plasmids would be useful in our fight against the pathogens (Dastidar et al., 2013; Molnar et al., 1992; Spengler et al., 2006). Plants are an important source of antimicrobial compounds and have played an important role in controlling diseases (Cowan, 1999; Dastidar et al., 2013; Imam et al., 2016; Mahady, 2005; Ta and Arnason, 2015). They still remain the primary source of medicine for both human and livestock in poorer and remote parts of the world. Identification of edible plants that may have anti-Bacillus anthracis activity would have direct impact on the prevention of anthrax and decreasing its occurrence in the poorer endemic regions.

The extracts from a number of plants from diverse geographical origins, mostly employing organic solvent extraction, have been indicated in literature to have anti-Bacillus anthracis activity (Akinpelu et al., 2008; Elisha et al., 2016; Mbwambo et al., 2011; Moshi and Mbwambo, 2005; Taher et al., 2012). In the current study, a number of edible plants commonly found in Indian subcontinent (Duke et al., 2002; U.S. Department of Agriculture, 1992-2016) were evaluated for anti-Bacillus anthracis activity. Although extraction of bioactive compounds from 
plants is more commonly performed using organic solvents such as ethanol, methanol, acetone, chloroform etc., we had consciously chosen water as the extractant in the current study because of its wider availability and ease of use in the field as compared to any other extractant. In the current study, a number of plants displayed water extractable anti-Bacillus anthracis activity including Garlic that had been indicated previously (Sasaki and Kita, 2003). The Aqueous Garlic Extract (AGE) exhibited a robust growth inhibition activity against Bacillus anthracis producing large $\mathrm{ZOI}$ which was also sustained for $72 \mathrm{~h}$ of incubation. A number of plants such as Turmeric, Onion and Tulsi, which are variously attributed to have high antimicrobial/bactericidal activity against a number of pathogens were found to be relatively inactive in the form tested, while Neem and Mango seemed to be moderately active (Duke et al., 2002; U.S. Department of Agriculture, 1992-2016). It is expected, as the plant extracts are supposed to contain a number of bioactive chemicals whose synergistic interactions are responsible for their overall activity against specific pathogens and hence the medicinal prescription (U.S. Department of Agriculture, 1992-2016). Among the tested aqueous extracts of various plants, the extract from Garlic was found to be the most potent that reproducibly inhibited Bacillus anthracis growth. However, the extract employed in the current study seemed to be relatively less active as compared to that used by Sasaki and Kita, 2003 (Sasaki and Kita, 2003). One of the reasons could be the difference in the bioactive content present in different preparations used, i.e., fresh garlic vs. dried powder and the methodology employed.

The vegetative cells of the Bacillus anthracis are known to be responsible for the pathogenesis primarily through production of the anthrax toxins. Any agent that may kill vegetative cells of Bacillus anthracis (Committee on Prepositioned Medical Countermeasures for the Public, 2012; Omotade et al., 2014) or that do not allow germination of spores are potent anti-Bacillus anthracis agents (Akoachere et al., 2007). When we tested the AGE for such activity, the AGE at concentrations $\geq 1.9 \% \mathrm{w} / \mathrm{v}$ displayed robust killing of vegetative cells of Bacillus anthracis and decreased the cell counts by more than 6 logs within 6-12 h of exposure indicating it to have a potent anti-Bacillus anthracis activity that may be further explored for controlling anthrax infection.

Virulence plasmids, pXO1 and pXO2 are responsible for the pathogenicity of Bacillus anthracis. If somehow Bacillus anthracis cells can be cured of these plasmids they would become avirulent (Kaur et al., 2013; Levy et al., 2012). Some small molecules such as acridine dyes are known to cause plasmid loss at sub-inhibitory concentration making virulent strains non-pathogenic (Molnar et al 1992; Mbwambo et al. 2011; Taher et al 2012). The ability of any safer antiBacillus anthracis agent to cause loss of the virulence plasmid(s) at sub-inhibitory concentration would further increase its utility to control anthrax. When we evaluated the AGE for such a plasmid curing ability at both growth sub-inhibitory and inhibitory dosages the results negated any such potential use of Garlic as no plasmid loss was observed at any tested concentration.

Bioactive content identification or characterization of any plant origin product is required to credibly correlate the constituent and their effect to recommend its preventive or curative use (Bhardwaj et al., 2013; Cowan, 1999; Friedman, 2015; Guil-Guerrero et al., 2016). The attempt to characterize the bioactive constituents present in AGE with anti-Bacillus anthracis bioactivity 
revealed the presence of chemical entities that belonged to different class of potential bioactive compounds such as phthalic acid derivatives, acid esters, phenyl group containing compounds, steroids etc. but conspicuously the well-known bioactive compounds such as alliin, ajoene, Sallyl-L-cysteine, Y-glutamyl-S-allyl-L-cysteine, allicin etc. (Goncagul and Ayaz, 2010) were absent suggesting compounds other than the well-knowns to be responsible for the observed anti-Bacillus anthracis activity. Further characterization of the bioactive fraction(s) is underway. Although garlic is used widely in food in the cooked form its intake in the uncooked raw form is relatively limited. The characterization of thermal stability of the anti-Bacillus anthracis activity present in AGE indicated it to be relatively stable at room temperature but quite unstable at $100^{\circ} \mathrm{C}$ - the temperature generally achieved during cooking. These observations combined with the previous observations that indicate raw Garlic or Garlic extract to be safe for consumption or injection ((HMPC), 2016) suggests that the usage of Garlic, in the raw form, may be helpful in controlling the incidence of anthrax in endemic areas.

Antimicrobial agents when present in combination(s) may synergize or antagonize each other's activity (Acar, 2000; Weiss et al., 2015; Wolfart et al., 2006). This kind of information is needed for successful usage of any new potential antimicrobial agent. When we tested AGE for its interaction with FDA approved antibiotics for anthrax prevention it was found to not antagonize the activity of antibiotics used for anthrax control, suggesting absence of any negative interaction.

Immediate future work may be focused on testing the efficacy of AGE alone or in combination with other common food ingredients in decreasing the Bacillus anthracis load in spiked animal tissue samples (meat) and the characterization of the bioactive fraction(s). Although AGE did not seem to promote virulence plasmid loss in our assay, ascertaining its effect on the expression of virulence factors, e.g., Protective Antigen (PA), Lethal Factor (LF), Edema Factor $(E F)$, and on quorum sensing would remain a priority to increase its potential utility in the anthrax control. Evaluation of the ability of Garlic to prevent the occurrence of gastrointestinal anthrax or evaluation of AGE as injectable for therapy purpose as it is well tolerated in model animals (HMPC), 2016) may be some other areas of exploration. Further work needs to be undertaken to explore the possibility of employing Garlic or AGE to decrease the incidence of anthrax in endemic areas.

Acknowledgement: The work was supported by a research grant 'Ramalingaswami Fellowship (BT/RLF/Re-Entry/50/2011)' from DBT, India to SS. Partial funding support to the laboratory of SS from DST-PURSE through Panjab University, Chandigarh is also duly acknowledged. The research funding agencies had no role in study design, data collection and analysis, decision to publish, or preparation of the manuscript.

Author Contributions and email addresses: Conceived and designed the experiments: SS (samersingh@gmail.com); Performed the experiments: RK (rajinderkaurabt@gmail.com), AT(atultiwari.microbio@gmail.com); Analyzed the data: RK, AT, SS; Contributed reagents/materials/analysis tools/discussion: RK, AT, MM (manishjnu8@gmail.com), IKM(inderwinner@gmail.com), RB(rakeshbhatnagar@jnu.ac.in) and SS; Wrote the paper: SS. 


\section{References:}

(HMPC), C.o.H.M.P., 2016. Assessment report on Allium sativum L., bulbus. London. Acar, J.F., 2000. Antibiotic synergy and antagonism. Med Clin North Am 84, 1391-1406.

Akinpelu, D.A., Adegboye, M.F., Adeloye, O.A. and Okoh, A.I., 2008. Biocidal activity of partially purified fractions from methanolic extract of Garcinia kola (Heckel) seeds on bacterial isolates. Biol Res 41, 277-287.

Akoachere, M., Squires, R.C., Nour, A.M., Angelov, L., Brojatsch, J. and Abel-Santos, E., 2007. Identification of an in vivo inhibitor of Bacillus anthracis spore germination. J Biol Chem 282, 12112-12118.

Bhardwaj, A.K., Vinothkumar, K. and Rajpara, N., 2013. Bacterial quorum sensing inhibitors: attractive alternatives for control of infectious pathogens showing multiple drug resistance. Recent Pat Antiinfect Drug Discov 8, 68-83.

Blaskovich, M.A., Butler, M.S. and Cooper, M.A., 2017. Polishing the tarnished silver bullet: the quest for new antibiotics. Essays Biochem 61, 103-114.

CDC, 2016. Anthrax: Recommendations.

Committee on Prepositioned Medical Countermeasures for the Public, I.o.M., Clare Stroud, Kristin Viswanathan, Tia Powell, and Robert R. Bass (Ed.), 2012. Prepositioning Antibiotics for Anthrax. National Academies Press (US), Washington (DC).

Cowan, M.M., 1999. Plant products as antimicrobial agents. Clin Microbiol Rev 12, 564-582.

Dastidar, S.G., Kristiansen, J.E., Molnar, J. and Amaral, L., 2013. Role of Phenothiazines and Structurally Similar Compounds of Plant Origin in the Fight against Infections by Drug Resistant Bacteria. Antibiotics (Basel) 2, 58-72.

Duke, J.A., Bogenschutz-Godwin, M.J., duCellier, J. and Duke, P-A.K., 2002. Handbook of medicinal herbs. CRC Press LLC, Boca Raton.

Duke J.A., Duke P-K., duCellie J.L.. Duke's handbook of medicinal plants of the Bible (2008), CRC Press Taylor \& Francis Group, 6000 Broken Sound Parkway NW, Suite 300 Boca Raton, FL 33487-2742. ISBN 978-0-8493-8202-4

Elisha, I.L., Dzoyem, J.P., Botha, F.S. and Eloff, J.N., 2016. The efficacy and safety of nine South African medicinal plants in controlling Bacillus anthracis Sterne vaccine strain. BMC Complement Altern Med 16, 5.

FDA, 2016. Drugs: Drug Information Related to Anthrax

Friedman, M., 2015. Antibiotic-resistant bacteria: prevalence in food and inactivation by foodcompatible compounds and plant extracts. J Agric Food Chem 63, 3805-3822.

Goncagul, G. and Ayaz, E., 2010. Antimicrobial effect of garlic (Allium sativum). Recent Pat Antiinfect Drug Discov 5, 91-93.

Guil-Guerrero, J.L., Ramos, L., Moreno, C., Zúñiga-Paredesa, J.C., Carlosama-Yepez, M. and Ruales, P., 2016. Antimicrobial activity of plant-food by-products: A review focusing on the tropics. Livestock Science 189, 32-49.

Hendricks, K.A., Wright, M.E., Shadomy, S.V., Bradley, J.S., Morrow, M.G., Pavia, A.T., Rubinstein, E., Holty, J.E., Messonnier, N.E., Smith, T.L., Pesik, N., Treadwell, T.A. and Bower, W.A., 2014. Centers for disease control and prevention expert panel meetings on prevention and treatment of anthrax in adults. Emerg Infect Dis 20. 
Imam, M.U., Ismail, M., Ooi, D.J., Azmi, N.H., Sarega, N., Chan, K.W. and Bhanger, M.I., 2016. Are bioactive-rich fractions functionally richer? Crit Rev Biotechnol 36, 585-593.

Kaur, M., Singh, S. and Bhatnagar, R., 2013. Anthrax vaccines: present status and future prospects. Expert Rev Vaccines 12, 955-970.

Kodera, Y., Suzuki, A., Imada, O., Kasuga, S., Sumioka, I., Kanezawa, A., Taru, N., Fujikawa, M., Nagae, S., Masamoto, K., Maeshige, K. and Ono, K., 2002. Physical, chemical, and biological properties of s-allylcysteine, an amino acid derived from garlic. J Agric Food Chem $50,622-632$.

Levy, H., Weiss, S., Altboum, Z., Schlomovitz, J., Glinert, I., Sittner, A., Shafferman, A. and Kobiler, D., 2012. Differential contribution of Bacillus anthracis toxins to pathogenicity in two animal models. Infect Immun 80, 2623-2631.

Mahady, G.B., 2005. Medicinal plants for the prevention and treatment of bacterial infections. Curr Pharm Des 11, 2405-2427.

Mbwambo, Z.H., Erasto, P., Nondo, R.O., Innocent, E. and Kidukuli, A.W., 2011. Antibacterial and cytotoxic activities of Terminalia stenostachya and Terminalia spinosa. Tanzan $\mathrm{J}$ Health Res 13, 119-124.

Molnar, J., Foldeak, S., Nakamura, M.J., Rausch, H., Domonkos, K. and Szabo, M., 1992. Antiplasmid activity: loss of bacterial resistance to antibiotics. APMIS Suppl 30, 24-31.

Mor V., Rella A., Farnoud A.M., Singh A., Munshi M., Bryan A., et al. 2015. Identification of a new class of antifungals targeting the synthesis of fungal sphingolipids. mBio 6(3):e00647-15.

Moshi, M.J. and Mbwambo, Z.H., 2005. Some pharmacological properties of extracts of Terminalia sericea roots. J Ethnopharmacol 97, 43-47.

Omotade, T.O., Bernhards, R.C., Klimko, C.P., Matthews, M.E., Hill, A.J., Hunter, M.S., Webster, W.M., Bozue, J.A., Welkos, S.L. and Cote, C.K., 2014. The impact of inducing germination of Bacillus anthracis and Bacillus thuringiensis spores on potential secondary decontamination strategies. J Appl Microbiol 117, 1614-1633.

Rahman, H., 2012. Epidemiology of anthrax in India. PD_ADMAS Technical Bulletin, India, Indian Council of Agricultural Research, New Delhi.

Rana, S.V., Pal, R., Vaiphei, K., Sharma, S.K. and Ola, R.P., 2011. Garlic in health and disease. Nutr Res Rev 24, 60-71.

Sasaki, J. and Kita, J., 2003. Bacteriocidal activity of garlic powder against Bacillus anthracis. J Nutr Sci Vitaminol (Tokyo) 49, 297-299.

Shadomy, S., Idrissi, A.E., Raizman, E., Bruni, M., Palamara, E., Pittiglio, C. and Lubroth, J., 2016. Anthrax outbreaks: a warning for improved prevention, control and heightened awareness. Empres watch.

Sharifi-Rad, J., Mnayer, D., Tabanelli, G., Stojanovic-Radic, Z.Z., Sharifi-Rad, M., Yousaf, Z., Vallone, L., Setzer, W.N. and Iriti, M., 2016. Plants of the genus Allium as antibacterial agents: From tradition to pharmacy. Cell Mol Biol (Noisy-le-grand) 62, 57-68.

Singh S., Ahuja N., Chauhan V., Rajasekaran E., Mohsin Waheed S., Bhat R. and Bhatnagar R., 2002. Gln277 and Phe554 residues are involved in thermal inactivation of protective antigen of Bacillus anthracis. Biochem Biophys Res Commun. 296(5),1058-62

Spengler, G., Molnar, A., Schelz, Z., Amaral, L., Sharples, D. and Molnar, J., 2006. The mechanism of plasmid curing in bacteria. Curr Drug Targets 7, 823-841. 
Ta, C.A. and Arnason, J.T., 2015. Mini Review of Phytochemicals and Plant Taxa with Activity as Microbial Biofilm and Quorum Sensing Inhibitors. Molecules 21, E29.

Taher, M., Susanti, D., Rezali, M.F., Zohri, F.S., Ichwan, S.J., Alkhamaiseh, S.I. and Ahmad, F., 2012. Apoptosis, antimicrobial and antioxidant activities of phytochemicals from Garcinia malaccensis Hk.f. Asian Pac J Trop Med 5, 136-141.

Turnbull, P. (Ed.), 2008. Anthrax in humans and animals. WHO Press, World Health Organization, Geneva, Switzerland.

Turnbull, P.C.B., Böhm, R., Cosivi, O., Doganay, M., Hugh-Jones, M.E., Joshi, D.D., Lalitha, M.K. and Vos, V.d., 1999. Guidelines for the Surveillance and Control of Anthrax in Humans and Animals. World Health Organization, Emerging and other Communicable Diseases, Surveillance and Control.

U.S. Department of Agriculture, A.R.S., 1992-2016. Dr. Duke's Phytochemical and Ethnobotanical Databases. U.S. Department of Agriculture, Agricultural Research Service Weiss, S., Altboum, Z., Glinert, I., Schlomovitz, J., Sittner, A., Bar-David, E., Kobiler, D. and Levy, H., 2015. Efficacy of Single and Combined Antibiotic Treatments of Anthrax in Rabbits. Antimicrob Agents Chemother 59, 7497-7503.

Wolfart, K., Spengler, G., Kawase, M., Motohashi, N., Molnar, J., Viveiros, M. and Amaral, L., 2006. Synergistic interaction between proton pump inhibitors and resistance modifiers: promoting effects of antibiotics and plasmid curing. In Vivo 20, 367-372. 


\section{Figure Legends:}

Figure 1. Common edible plants have anti-Bacillus anthracis activity. The aqueous plant extracts prepared from different plants were placed in the wells made in the solidified MHA medium followed by spreading of exponentially growing Bacillus anthracis culture on the plate and incubation at $37^{\circ} \mathrm{C}$ for upto $72 \mathrm{~h}$ (see Materials and Methods for details). The growth pattern of the test organism on the MHA plates varied as apparent from different diameters of the zone of growth inhibition (ZOI) - (A) Bael (Aegle marmelos (L.) Correa) leaf: BE; Daruharidra (Berberis asiatica Roxb. ex DC) leaf: DA.; Guava (Psidium guajava L.) leaf: GU; common grass (Cynodon dactylon L.): GR; Mango (Mangifera indica L.) leaf: MA; Neem (Azadiracta indica A. Juss.) leaf: NE; Shetuta (Morus indica L.) leaf: SH; (B) Coriander (Coriandrum sativum L.) leaf: CO; Garlic (Allium sativum L.) bulb: GA; Ginger (Zingiber officinale Roscoe) rhizome: Gl; Onion (Allium cepa L.) bulb: ON; Tulsi (Ocimum sanctum L.) leaf: TU; Turmeric (Curcuma longa L.) rhizome: TR; Ram Tulsi (Ocimum gratissimum L.) leaf: RTU. The Aqueous Garlic Extract (AGE) appeared to be the most potent based upon the ZOI produced by the aqueous extracts made from equal wet weight of plant parts tested (See Table 1). The ZOI initially produced by Neem leaf and Mango leaf extract were short lived and disappeared by $48 \mathrm{~h}$ of incubation (See Table 1). Each plate included antibiotic Rifampicin as a positive control (+ Ctrl), and ultrapure water as solvent control (- Ctrl). Note: The aqueous extract from Guava leaf did not produce any ZOI in the displayed plate. (C) Aqueous Garlic (Allium sativum) Extract (AGE) inhibits growth of Bacillus anthracis. The exponentially growing Bacillus anthracis culture was diluted in fresh MHB growth medium so as to have optical density at $600 \mathrm{~nm}\left(\mathrm{OD}_{600}\right)$ of 0.1 , supplemented with $0-3.6 \% \mathrm{w} / \mathrm{v}$ of $\mathrm{AGE}$ and the growth was monitored by measuring $\mathrm{OD}_{600}$ at different time intervals. Note: The aqueous Garlic (Allium sativum) extract supplementation of $\geq 1.9 \% \mathrm{w} / \mathrm{v}$ inhibited the growth of exponentially growing Bacillus anthracis culture. The values shown are average of three independent experiments $(n=3)$ and the error bars represent standard error of mean. (D) Photograph of Gram stained exponentially growing Bacillus anthracis cells ( $0 \% \mathrm{w} / \mathrm{v}$ AGE).

Figure 2. Aqueous Garlic (Allium sativum) Extract (AGE) kills Bacillus anthracis cells. (A) The exposure to AGE induces morphological changes in Bacillus anthracis cells. Scanning Electron Microscopy (SEM) image of the exponentially growing Bacillus anthracis cells (top panel; control cells) and those exposed to $1.9 \% \mathrm{w} / \mathrm{v}$ AGE for $3 \mathrm{~h}$ (bottom panel; treated cells) indicate the disintegration of longer chains and appearance of smaller chains and single cells in 
the AGE exposed Bacillus anthracis culture (compare control cells in top panel with AGE treated cells in the bottom panel). The exposure of exponentially growing Bacillus anthracis cells to AGE $\left(0-3.6 \% \mathrm{w} / \mathrm{v}\right.$ at $\left.37^{\circ} \mathrm{C}\right)$ in MHB medium (B) as well as normal saline (C) results in progressive loss of the cells viability as indicated by the progressive decrease in the remaining $\mathrm{CFU} / \mathrm{mL}$ with increase in exposure time. Note the survival of exponentially growing Bacillus anthracis cells appears to be differentially affected by the presence of growth medium components on AGE exposure. The CFU/ml values are average of three independent experiments $(n=3)$ and the error bars represent standard deviation.

Figure 3. Aqueous Garlic Extract (AGE) at sub-inhibitory concentration does not promote virulence plasmid 'pX01' loss from Bacillus anthracis Sterne strain. The Bacillus anthracis cells were grown in MHB medium in the presence of sub-inhibitory concentration of AGE $(1 \%$ $\mathrm{w} / \mathrm{v}$ ) and the loss of virulence plasmid pXO1 from cells was assessed at different time intervals $(0$ - $24 \mathrm{~h}$ ). The presence of pXO1 borne pagA gene as well as genome borne phoP gene was assessed by PCR amplification of the said genes using gene specific primers (see materials and methods). (A) The analysis of eight random colonies picked from $24 \mathrm{~h}$ old AGE exposed culture for the presence of $p a g A$ and $p h o P$ genes are shown. All colonies examined retained the pXO1 plasmid based upon the PCR amplification of pagA gene. Genomic DNA from Bacillus anthracis Sterne strain was used as positive control and that of Escherichia coli DH5a strain as negative control for the PCR based analysis. (B) The overall summary of the virulence plasmid pXO1 loss assay is presented in tabular form. Bacillus anthracis cells seem to not lose pXO1 on AGE exposure at all the time points tested $(0-24 \mathrm{~h})$.

Figure 4. Characterization of Aqueous Garlic (Allium sativum) Extract (AGE). (A-B) Exposure of AGE to higher temperature decreases its potency to inhibit growth of Bacillus anthracis. The result of agar-well diffusion assay to assess the anti-Bacillus anthracis activity remaining in AGE incubated for $6 \mathrm{~h}$ at various temperatures $\left(4-50^{\circ} \mathrm{C}\right)$ is shown in $(\mathrm{A})$. The $50 \mu \mathrm{l}$ aliquots from the AGE extracts incubated at different temperatures, as labeled in figure, were loaded in the wells made in MHA plate along with $8 \mu \mathrm{g}$ of antibiotic Rifampicin as positive control in the well that is marked as positive (+) followed by overnight incubation of the plate at $37^{\circ} \mathrm{C}$. (B) The relative decrease in potency of AGE incubated upto 15 days at temperatures $4-50^{\circ} \mathrm{C}$ to inhibit Bacillus anthracis growth was assessed in terms of zone of growth inhibition (ZOI) observed in agar-well diffusion assays as shown in (A). The data indicated incremental loss in 
the anti-Bacillus anthracis activity of AGE with increase in temperature and the incubation duration. The data is presented as ZOI with respect to (WRT) that shown by AGE incubated at $4^{\circ} \mathrm{C}$, which did not seem to lose activity and consistently gave a ZOI of 17-19 mm upto 15 days of incubation. The freshly prepared AGE does not seem to lose anti-Bacillus anthracis activity rapidly near room temperature (see data for upto $40^{\circ} \mathrm{C}$ incubation). The AGE incubated at $40^{\circ} \mathrm{C}$ retained $>80 \%$ activity even after incubation for 1 day. (C-D) Garlic samples/batches display similar anti-Bacillus anthracis activity. The Garlic samples purchased at different times from local market of Chandigarh, India were evaluated for the presence of bioactive principles to ascertain the relative consistency of the batches in terms of the anti-Bacillus anthracis activity profile. (C) The aqueous extracts made from different Garlic sample batches were compared for the relative potency against Bacillus anthracis using agar-well diffusion assay as described before. All three batches displayed similar potency as apparent from their ZOI. (D) Summary of the assay shown in $(\mathrm{C})$. Note: The identity of sample no. 1 was further verified as Allium sativum through sequencing of the rbcL gene (see material methods).

Figure 5. Aqueous Garlic (Allium sativum) Extract (AGE) does not antagonize the antiBacillus anthracis activity of the commonly employed antibiotics for anthrax control activity of. (A) The antibiotics commonly employed for anthrax control, i.e., Amoxicillin (Am), Cefixime (Ce), Ciprofloxacin (C), Doxycycline (Dox) Levofloxacin (L) Penicillin (P) Rifampicin (R) Tetracycline(T) along with Sulfamethoxazole (S), an antibiotic known to be ineffective against Bacillus anthracis were assayed for possible interaction with AGE using agar well diffusion assay. The top and bottom panels in are from experiment performed with different concentration of the indicated test substances. Except Sulfamethoxazole, all antibiotics and AGE inhibited the growth of Bacillus anthracis as expected. (B) Summary of the interaction of AGE with antibiotics in inhibiting Bacillus anthracis growth as apparent from (A). The AGE did not interact negatively with antibiotics currently employed for anthrax control rather displayed some degree of synergy (see the shape of ZOI produced around wells loaded with different antibiotics in panel A). Summary of the relative ability of different tested substances in inhibiting Bacillus anthracis growth is provided in Sup. Fig. 6. (C) A representative microdilution experiment for MIC and $\mathrm{FICl}$ value calculation of $\mathrm{AGE}$ and antibiotic is shown. In the plate shown Tetracycline (i.e., 1.25 - $0.009 \mu \mathrm{g} / \mathrm{mL}$; black) and AGE (i.e., 100 - $0.78 \mathrm{mg} / \mathrm{mL}$; red) were taken in combination to determine their synergistic, antagonist or indifferent effect on the growth of $B$. anthracis. The concentration of tetracycline and AGE alone decreased from left to right as indicated (row $A$ and $\mathrm{H}$ ) while the concentration of $A G E$ in combination with the indicated fixed concentration of 
antibiotic increased from bottom to top (row $\mathrm{G}$ to $\mathrm{B}$ ) as indicated by arrows. Column 9 and 10 are the duplicates of row $A$ and $H$ respectively. Wells $A 11-12$ is media control (-Ctrl) and B11-12 is cell control, i.e., B. anthracis cells without any antibiotics or AGE. Values indicated in blue circle indicate the MIC value of tetracycline (i.e., $0.078 \mu \mathrm{g} / \mathrm{mL}$ ) and AGE (i.e., $12.5 \mathrm{mg} / \mathrm{mL}$ ) alone in row $A$ and $H$ respectively. Values indicated in yellow circle indicate the concentration of tetracycline and AGE in combination (i.e., $0.039 \mu \mathrm{g} / \mathrm{ml}$ and $6.25 \mathrm{mg} / \mathrm{ml}$ respectively). (D) The MIC values of antibiotics and AGE in combination and alone was used in calculating fractional inhibitory concentration index $(\mathrm{FICl})$ to determine synergistic, antagonist or indifferent effect on the growth of $B$. anthracis (values shown in table). The values represent range of at least three experiments performed independently.

Table 1. Inhibition of Bacillus anthracis growth by aqueous (sterile ultrapure water) extract of indicated plants. The aqueous extracts of different plants $(40 \% \mathrm{w} / \mathrm{v})$ were tested for their ability to inhibit the growth of Bacillus anthracis in agar well diffusion assay (see Materials and Methods for details). The growth pattern of the test organism was monitored for 12-72 $\mathrm{h}$. The data shown is from one representative experiment. The controls included in each plate were antibiotic Rifampicin as a positive control (+ Ctrl) and ultrapure water which was used as solvent/diluent as negative control (- Ctrl). Note: Garlic has the highest concentration of watersoluble anti-Bacillus anthracis activity constituents among the tested plants.

Table 2. Partial list of potential bioactive compounds in AGE. The list is made from compound hits in the fractions that showed anti-Bacillus anthracis activity. For the complete list of compound hits please refer to Supplementary Figures 2-5. 


\begin{tabular}{|c|c|c|c|c|c|c|c|}
\hline \multirow[t]{2}{*}{$\begin{array}{l}\text { S. } \\
\text { No. }\end{array}$} & \multirow{2}{*}{$\begin{array}{l}\text { Name of the plant as per } \\
\text { http://www.theplantlist.org } \\
\text { (common } \\
\text { name) - plant part used (L: } \\
\text { Leaf; B: bulb; Fruit: F; } \\
\text { Rhizome: R) }\end{array}$} & \multirow[t]{2}{*}{ Site of collection } & \multicolumn{4}{|c|}{$\begin{array}{l}\text { Zone of Inhibition (in mm) } \\
\text { after incubation for }\end{array}$} & \multirow{2}{*}{$\begin{array}{c}\text { Volume } \\
\text { of crude } \\
\text { aqueous } \\
\text { extract }\end{array}$} \\
\hline & & & $12 \mathrm{~h}$ & $24 \mathrm{~h}$ & $48 \mathrm{~h}$ & $72 \mathrm{~h}$ & \\
\hline 1. & $\begin{array}{l}\text { Aegle marmelos (L.) Correa } \\
\text { ( Bael, Bengal Quince) - L }\end{array}$ & $\begin{array}{c}\text { Panjab University campus, } \\
\text { Chandigarh (Chd.) }\end{array}$ & 0 & 0 & 0 & 0 & $50 \mu l$ \\
\hline 2. & Allium cepa L. (Onion) - B & Local market, Chd. & 0 & 0 & 0 & 0 & $50 \mu l$ \\
\hline 3. & $\begin{array}{l}\text { Allium sativum L. (Garlic) - } \\
\text { B }\end{array}$ & Local market, Chd. & 19 & 19 & 18 & 18 & $50 \mu l$ \\
\hline 4. & $\begin{array}{l}\text { Azadirachta indica A. Juss. } \\
\text { (Neem) - L }\end{array}$ & $\begin{array}{c}\text { Panjab University campus, } \\
\text { Chd. }\end{array}$ & 11 & 10 & 0 & 0 & $50 \mu l$ \\
\hline 5. & $\begin{array}{l}\text { Berberis asiatica Roxb. ex } \\
\text { DC. (Daruharidra) - L }\end{array}$ & $\begin{array}{c}\text { Panjab University campus, } \\
\text { Chd. }\end{array}$ & 0 & 0 & 0 & 0 & $50 \mu l$ \\
\hline 6. & $\begin{array}{l}\text { Coriandrum sativum } \mathrm{L} \text {. } \\
\text { (Coriander, Cilantro) - L }\end{array}$ & Local market, Chd. & 0 & 0 & 0 & 0 & $50 \mu \mathrm{l}$ \\
\hline 7. & $\begin{array}{l}\text { Curcuma longa } \mathrm{L} \text {. } \\
\text { (Turmeric) - R }\end{array}$ & Local market, Chd. & 0 & 0 & 0 & 0 & $50 \mu l$ \\
\hline 8. & $\begin{array}{l}\text { Cynodon dactylon (L.) Pers. } \\
\text { (Bermuda grass, Doob) - L }\end{array}$ & $\begin{array}{c}\text { Panjab University campus, } \\
\text { Chd. }\end{array}$ & 0 & 0 & 0 & 0 & $50 \mu l$ \\
\hline 9. & $\begin{array}{l}\text { Mangifera indica L.(Mango)- } \\
\mathrm{L}\end{array}$ & $\begin{array}{c}\text { Panjab University campus, } \\
\text { Chd. }\end{array}$ & 10 & 10 & 0 & 0 & $50 \mu l$ \\
\hline 10. & $\begin{array}{l}\text { Ocimum tenuiflorum L. } \\
\text { (Ocimum sanctum L.; Holy } \\
\text { Basil, Tulsi) - L }\end{array}$ & $\begin{array}{c}\text { Panjab University campus, } \\
\text { Chd. }\end{array}$ & 0 & 0 & 0 & 0 & $50 \mu l$ \\
\hline 11. & $\begin{array}{l}\text { Ocimum gratissimum L. } \\
\text { (Ram Tulsi) - L }\end{array}$ & $\begin{array}{c}\text { Panjab University campus, } \\
\text { Chd. }\end{array}$ & 0 & 0 & 0 & 0 & $50 \mu l$ \\
\hline 12. & $\begin{array}{l}\text { Morus indica L. (Black } \\
\text { Mulberry, Shetuta) -L }\end{array}$ & $\begin{array}{c}\text { Panjab University campus, } \\
\text { Chd. }\end{array}$ & 0 & 0 & 0 & 0 & $50 \mu l$ \\
\hline 13. & $\begin{array}{l}\text { Psidium guajava L. } \\
\text { (Guvava) - L }\end{array}$ & $\begin{array}{c}\text { Panjab University campus, } \\
\text { Chd. }\end{array}$ & 0 & 0 & 0 & 0 & $50 \mu l$ \\
\hline 14. & $\begin{array}{l}\text { Zingiber officinale Roscoe } \\
\text { (Ginger) - R }\end{array}$ & Local market, Chd. & 0 & 0 & 0 & 0 & $50 \mu l$ \\
\hline - Ctr & $\begin{array}{l}\text { Solvent control (Ultrapure } \\
\text { Water) }\end{array}$ & & 0 & 0 & 0 & 0 & $50 \mu \mathrm{l}$ \\
\hline+ & Rifampicin $(8 \mu \mathrm{g})$ & & 18 & 18 & 18 & 17 & + \\
\hline
\end{tabular}

${ }^{\#}$ Refer to Table S1. for the details and references for the traditional use of plants 
Table 2. Partial list of potential bioactive compounds in AGE

\begin{tabular}{|c|c|}
\hline $\begin{array}{l}\text { Phthalic } \\
\text { acid } \\
\text { derivatives }\end{array}$ & $\begin{array}{l}\text { Phthalic acid, 2-hexyl ester; } \\
\text { Phthalic acid, butyl -2-pentyl ester; } \\
\text { Phthalic acid, butyl dodecyl ester; } \\
\text { Phthalic acid, butyl hex-3-yl ester }\end{array}$ \\
\hline $\begin{array}{l}\text { Acid- } \\
\text { esters }\end{array}$ & $\begin{array}{l}\text { Docosanoic acid, 1,2,3 propanetriyl ester; Dodecanoic acid, tricosafluoro } \\
\text { Cyclohexanecarboxylic acid,-1-(3,4-dimethoxyphenyl),(3-chloro-4-methylphenyl) amide } \\
\text { Benzoic acid 2,6-bis[(trimethylsilyl)oxy],trimethylsilyl ester } \\
\text { Benzoic acid, 2,5-bis(trimethylsiloxy)-trimethylsilyl ester } \\
\text { [(1H)-Pyrrole-3-propanoic acid-2-ethoxycarbonyl-4-ethoxycarbonylmethyl]-5,5'- } \\
\text { methylene,-bis,-diethyl ester } \\
\text { 2(Isobutoxycarbonyl)benzoic acid } \\
\text { Acetic acid,17-[1-hydroxy-1-,5dimethyl-5(Tetrahydropyran-2-yl-oxy)hex-2-ynyl]-10,13- } \\
\text { dimethyl-11-oxohexadecaydrocyclopenta[a]phenanthr-3yl-(ester) }\end{array}$ \\
\hline $\begin{array}{l}\text { Phenyl } \\
\text { group } \\
\text { containing }\end{array}$ & $\begin{array}{l}\text { Thiophene, 2,3,5tris(diphenylphosphino)1,3,4(6H)-Thiadiazin-2-amine,6-ethyl5phenyl- } \\
\text { 2-Amino-4-(4-bromophenyl) 6-methyl-5,6,7,8-tetrahydro[ 1,6] naphthyridine-3-carbonitrile } \\
\text { 2H-1,4-Benzodiazepin-2-one,7-chloro-1,3-dihydro5phenyl-1-(trimethylsilyl)-3[ } \\
\text { (trimethylsilyl)oxy] } \\
\text { Cyclohexanecarboxylic acid,-1-(3,4-dimethoxyphenyl),(3-chloro-4-methylphenyl) amide } \\
\text { Fluoren-9-ol,3,6-dimethoxy-9-(2-phenylethynyl) } \\
\text { Octaphenylcyclotetrasiloxane } \\
\text { Pregn-5-en-20-one,-3,16,17,21-tetrakis[(trimethylsilyl)oxy],-O- } \\
\text { (phenylmethyl)oxime,(3á,16à) } \\
\text { Silane,[[4-[1,2-bis[(trimethylsilyl)oxy]ethyl]-1,2-phenylene]-bis(oxy)]-bis[trimethyl }\end{array}$ \\
\hline $\begin{array}{l}\text { Steroids \& } \\
\text { Others }\end{array}$ & $\begin{array}{l}\text { 19-Norpregna1,3,5,7,9-pentaen-21-al, 3,17-bis[(trimethylsilyl)oxy],-O-methyloxime,(17à) } \\
\text { Pregn-4-en-18-al,3,20-bis(methoxyimino)-11,21-bis[(trimethylsilyl)-oxy],-O-methyloxime, } \\
\text { (11á,17à) } \\
\text { Pregn-4-ene-3,11,20-trione, 6,17,21-tris[(trimethylsilyl)oxy],-3,20-bis(O-methyloxime), } \\
\text { (6á) } \\
\text { Pregn-4-ene-3,20-dione,11,17,21-tris[(trimethylsilyl)oxy],Bis-(O-methyloxime),(11á) } \\
\text { Pregn-5-en-20-one,3,11,17,21-tetrakis[(trimethylsilyl)oxy],O-methyloxime,(3á,11á) } \\
\text { Pregn-5-en-20-one,-3,16,17,21-tetrakis[(trimethylsilyl)oxy],-O- } \\
\text { (phenylmethyl)oxime,(3á,16à) } \\
\text { Ole-12-ene-3,16,21,22,23,28-hexol, (3á,4à,16à,21á,22à) } \\
\text { Olean-12-ene-3,16,21,22,23,28-hexol, (3á,4á,16à,21á,22à) } \\
\text { Olean-12-ene-3,16,21,22,28-pentol,21(2-methyl2butenoate), [3á,16à,21á(Z),22à] } \\
\text { Lanostane-7,11-dione,3,18-bis(acetyloxy),-cyclic-7-(1,2-ethanediyl mercaptole), } \\
\text { (3á,20.xi.) } \\
\text { Cholestan-26-oic acid,3,7,12,24tetrakis(acetyloxy),-methyl ester,(3à,5á,7à,12à) } \\
\text { Cholestane-3,7,12,25-tetrol,tetraacetate,(3à,5á,7à,12à) } \\
\text { Cholestano[7,8a]cyclobutane,3-methoxy-6-oxo-2-methylene } \\
\text { 5á-Cholestane-3à, 7à,12à,24,25,26-hexol } \\
\text { 4aà,4bá-Gibbane-1à,10á-dicarboxylic acid, 4a-formyl-7-hydroxy-1-methyl-8 methylene, } \\
\text { dimethyl ester }\end{array}$ \\
\hline $\begin{array}{l}\text { Known } \\
\text { hits }\end{array}$ & $\begin{array}{ll}\text { Hematoporphyrin(ROS producer); } & \text { Lycophyll (a carotenoid pigment) } \\
\text { Rhodoxanthin (pigment); } & \text { Withaferin A (antimicrobial) }\end{array}$ \\
\hline
\end{tabular}




\section{Supplementary Table 1. Traditional use of plants as indicated in literature}

Supplementary Figure 1. Optimization of Thin Layer Chromatography (TLC) conditions in combination with bioautography to fractionate bioactive components present in Aqueous Garlic (Allium sativum) Extract (AGE). (A) Different solvent systems were evaluated for their ability to separate the components present in AGE. The thin layer of silica (TLC plate) was spotted with AGE followed by development of chromatogram using the indicated solvents. The fluorescent spots fractionated in AGE chromatograms were visualized under UV light. Some solvent combinations were found to better resolve fluorescent spots than others (compare chromatogram no. 3 with others). (B) The bioautography of AGE components separated on silica TLC using solvent system Toluene: Acetone (7:3) showed inhibition of the growth of Bacillus anthracis culture at specific position (encircled in white in right panel: Aqueous Garlic Extract or AGE TLC plate; chromatogram labeled 2) that correlated with UV-fluorescent spots visible in the upper middle part of the chromatogram 3 in (A) while the TLC plate that had only extractant water spotted and treated the same way (Left panel: Control TLC plate; chromatogram labeled 1), did not generate any zone of growth inhibition.

Supplementary Figure 2: GC-MS analysis of the TLC separated bioactive fraction of Aqueous Garlic (Allium sativum) Extract (AGE) to identify potential bioactive compounds: The UV fluorescent bands in the AGE chromatogram (Silica TLC) that corresponded with anti-Bacillus anthracis activity (growth inhibition) on the bioautogram were labeled G1 and G2 (A), isolated and processed for GC-MS analysis on Thermo Scientific TSQ 8000 Gas Chromatograph - Mass Spectrometer, using latest NIST Library (B and Sup. Figure 3 and 4). The well-known antimicrobials reported in Garlic, i.e., allicin, ajoene, allyl sulphides, could not be detected but other class of compounds with potential antimicrobial activity, e.g., phthalic acid derivatives, acid esters, phenyl group containing compounds, steroids, were detected (Sup. Figure 3 and 4). However, the GC-MS analysis of butanolic extract of garlic (C) showed the presence of various allyl derivatives as well as multiple S-containing compounds (Sup. Figure 5) suggesting the possible loss of allyl compounds in our processing of Garlic or their absence in the AGE as bioactive constituents.

Supplementary Figure 3. GC-MS profile of bioactive G1 spot from AGE and the list of compound hits 
Supplementary Figure 4. GC-MS profile of bioactive G2 spot from AGE and the list of compound hits

Supplementary Figure 5. GC-MS profile of butanolic extract of Garlic and the list of compound hits

Supplementary Figure 6. Zone of inhibition of antibiotics used in anthrax control and AGE 

aCC-BY-NC 4.0 International license.

A.
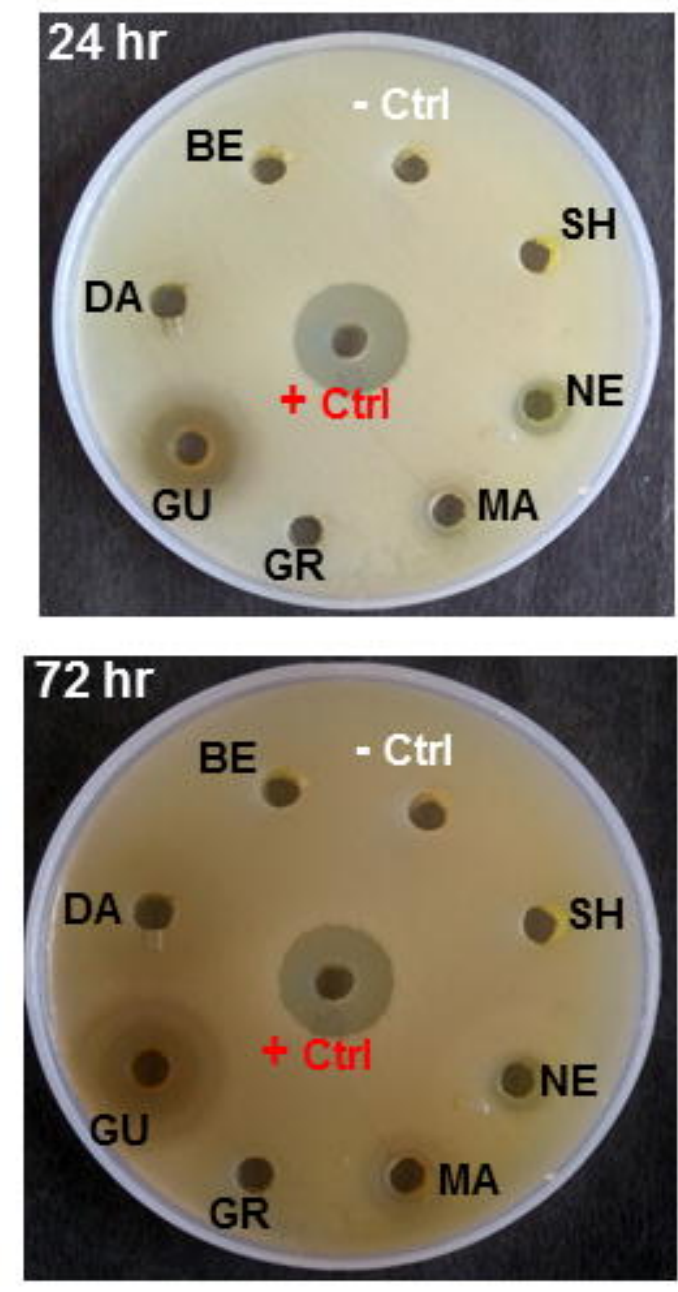

B.
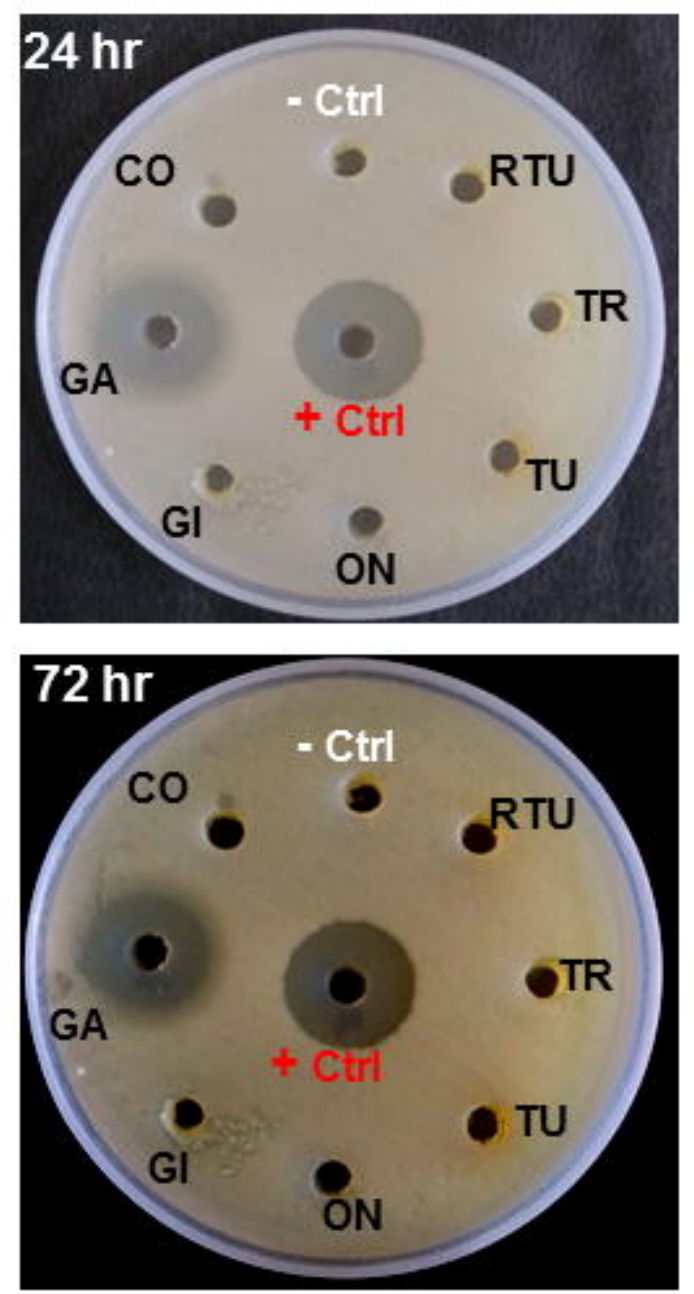

C.

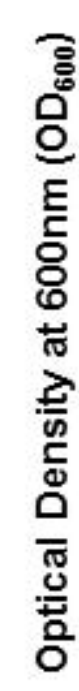

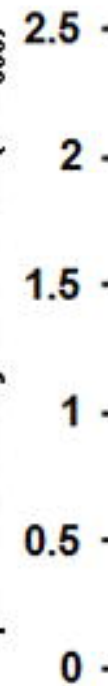

$\multimap 0 \%$ w/v AGE

$\multimap 1 \%$ w/v AGE

$-1.9 \%$ w/v AGE

$-3.6 \%$ w/v AGE

5
1
.5
0

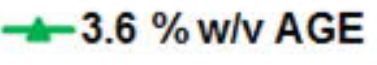


A.

Magnification: 1700X
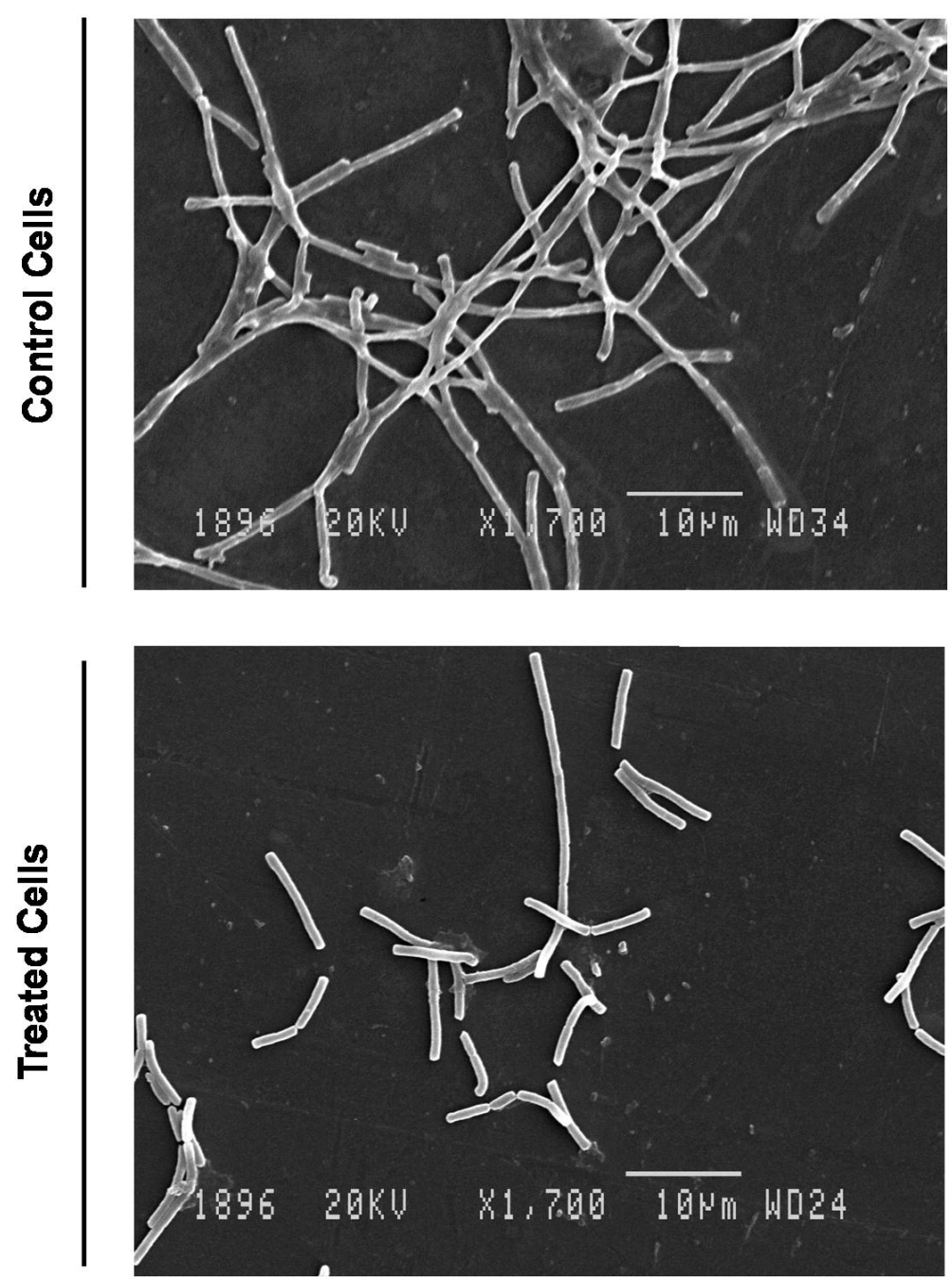

Magnification: $\mathbf{3 0 0 0 X}$
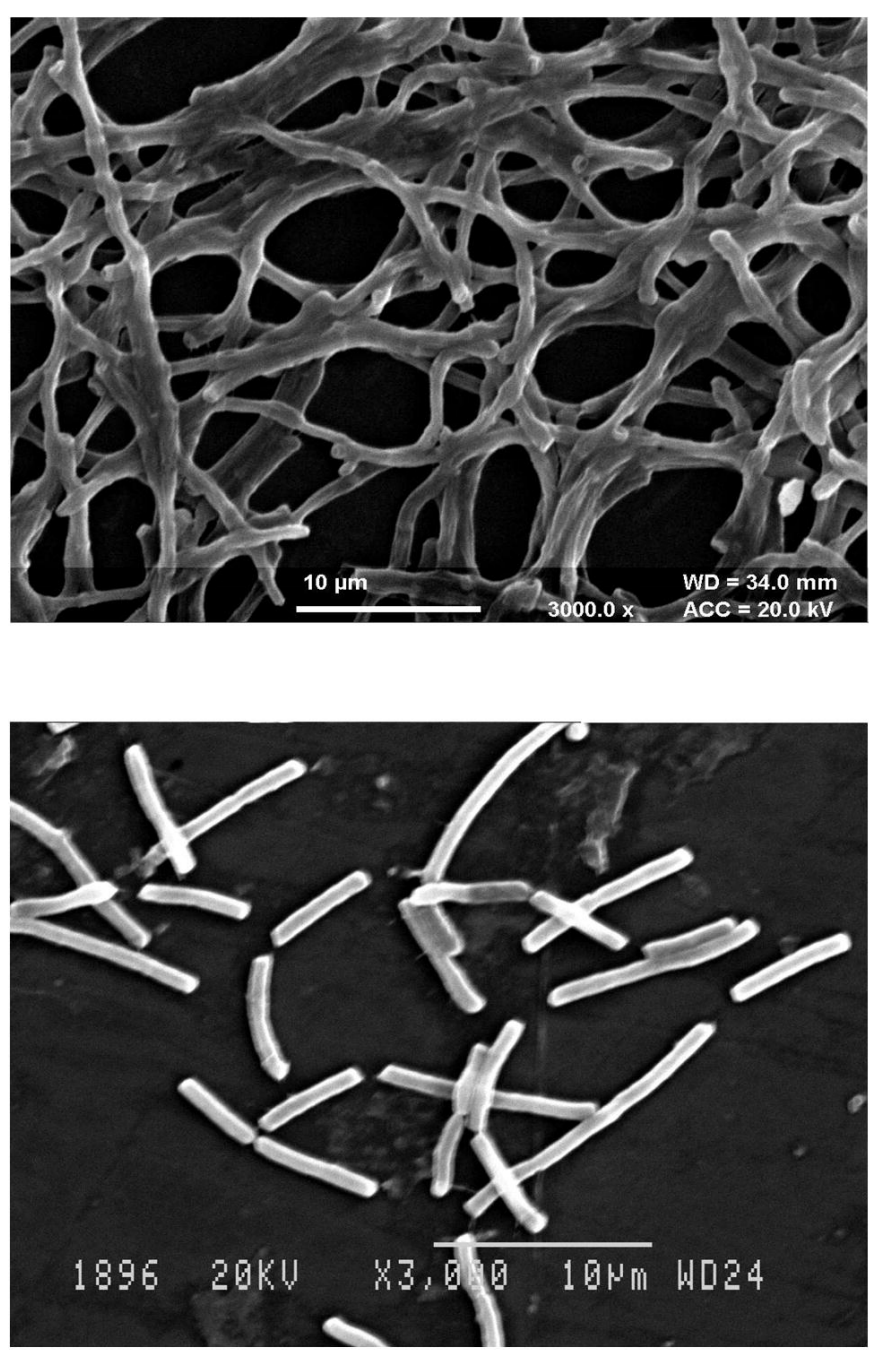

B.

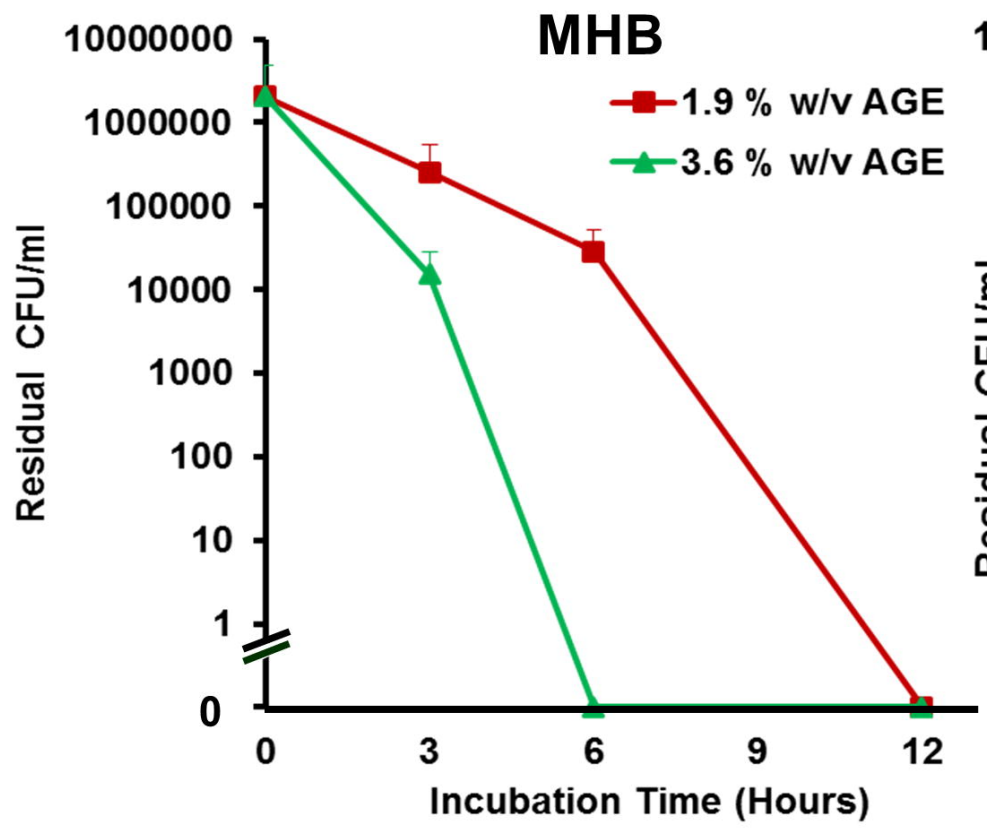

C.

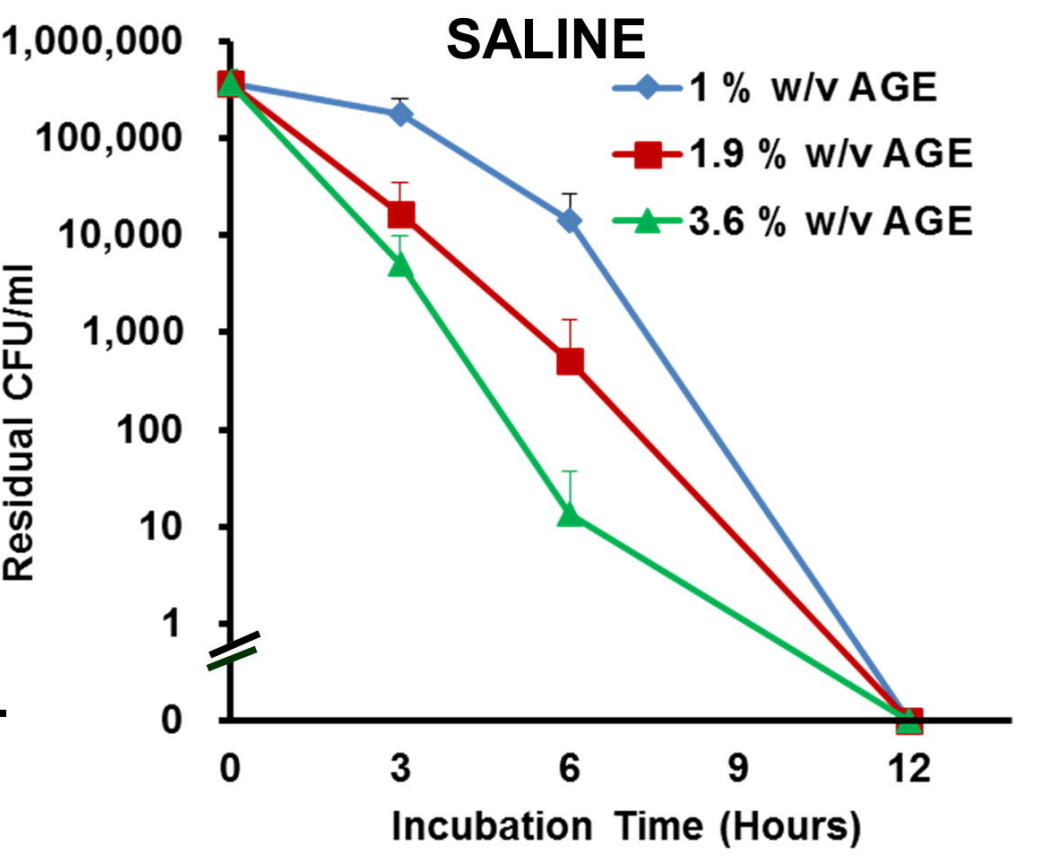


A.

Colony No.

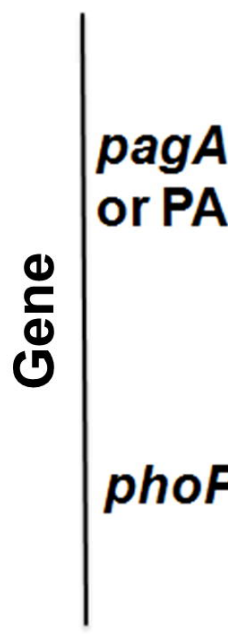

\begin{tabular}{llllllll}
\hline 1 & 2 & 3 & 4 & 5 & 6 & 7 & 8
\end{tabular}
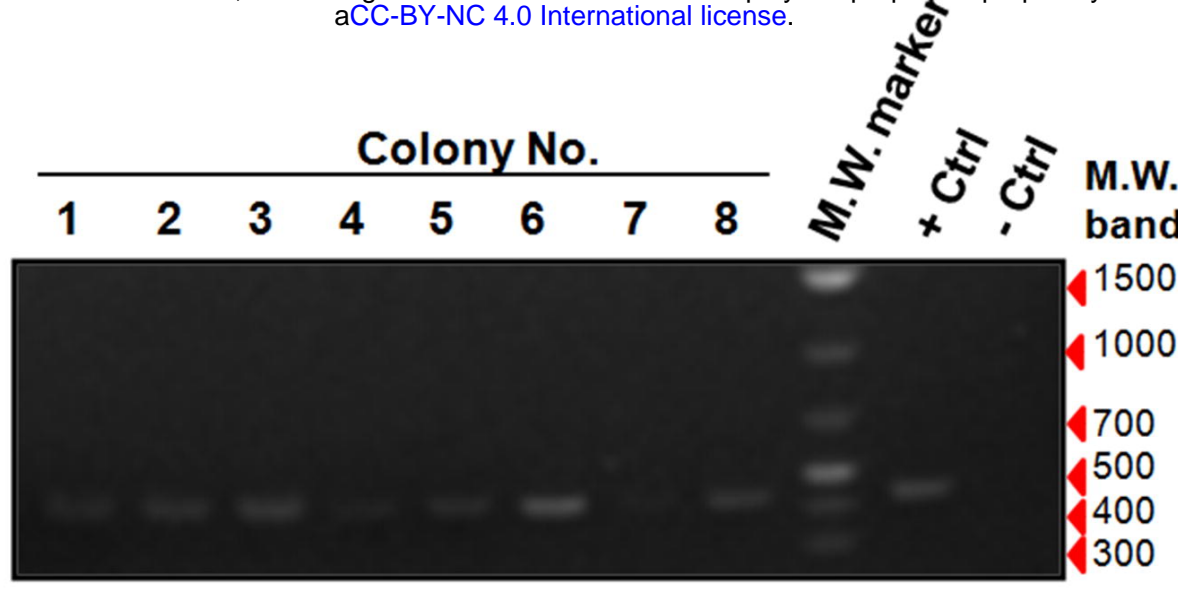

M.W. marker band size (bp)

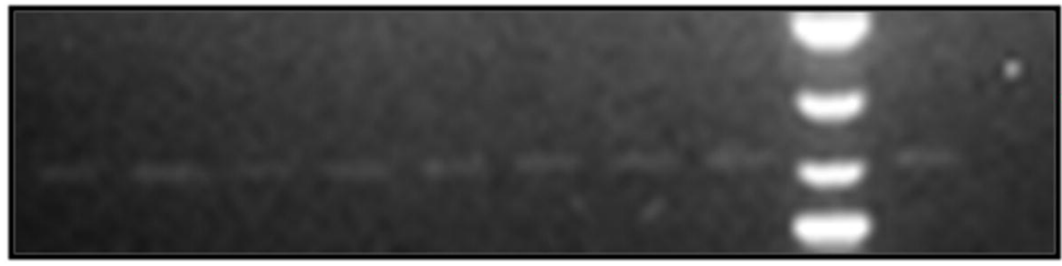

11500

1000

1700

4500

\section{B. Summary of Virulence Plasmid Loss Assay}

\begin{tabular}{|c|c|c|c|c|c|c|c|}
\hline \multirow[t]{2}{*}{ Genes tested (borne) } & \multicolumn{5}{|c|}{$\begin{array}{l}\text { Bacillus anthracis cells exposed } \\
\text { to AGE (hrs) }\end{array}$} & \multirow[t]{2}{*}{$\begin{array}{c}\text { 1+ve } \\
\text { control }\end{array}$} & \multirow[t]{2}{*}{$\begin{array}{c}\text { 2-ve } \\
\text { control }\end{array}$} \\
\hline & $0 \mathrm{hr}$ & $3 \mathrm{hr}$ & $6 \mathrm{hr}$ & $12 \mathrm{hr}$ & $24 \mathrm{hr}$ & & \\
\hline $\begin{array}{l}\text { pagA or PA gene ( } \mathrm{pXO1}) \\
\text { detected in no. of colonies/ } \\
\text { Total no. of colonies tested }\end{array}$ & $10 / 10$ & $10 / 10$ & $9 / 10$ & $10 / 10$ & $8 / 8$ & $1 / 1$ & $0 / 1$ \\
\hline $\begin{array}{l}\text { phoP gene (Chromosome) } \\
\text { detected in no. of colonies/ } \\
\text { Total no. of colonies tested }\end{array}$ & $10 / 10$ & $10 / 10$ & $10 / 10$ & $10 / 10$ & $8 / 8$ & $1 / 1$ & $0 / 1$ \\
\hline
\end{tabular}

${ }^{1}$ Untreated Bacillus anthracis Sterne Strain

${ }^{2}$ Escherichia coli DH5 $\alpha$ 
bioRxiv preprint doi: https://doi.org/10.1101/162214; this version posted July 29, 2018. The copyright holder for this preprint (which was not A certified by peer review) is the author/funder, who has anted bioRxiv a license to display the preprint in perpetuity. It is made available under
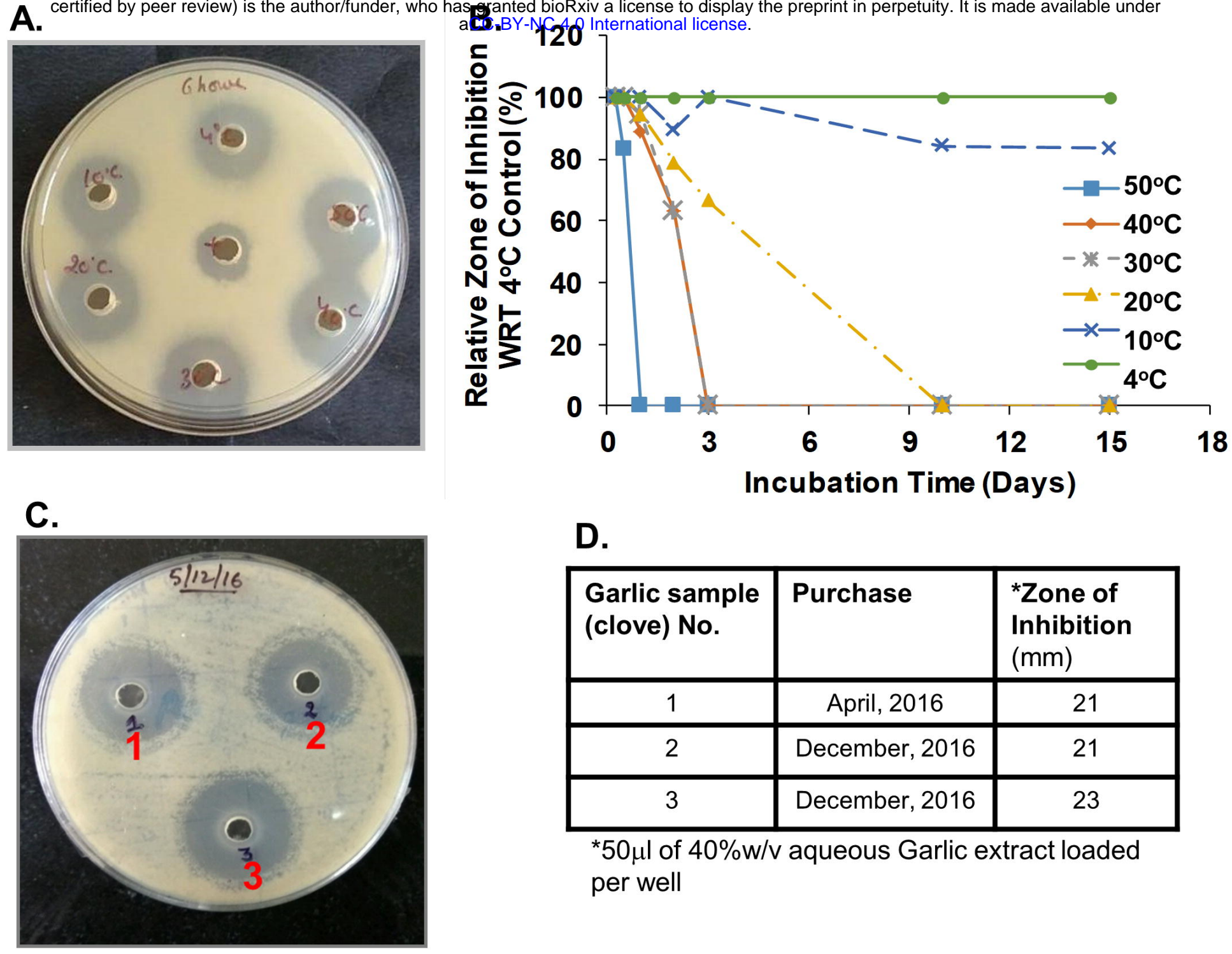

D.

\begin{tabular}{|c|l|c|}
\hline $\begin{array}{l}\text { Garlic sample } \\
\text { (clove) No. }\end{array}$ & Purchase & $\begin{array}{l}\text { *Zone of } \\
\text { Inhibition } \\
\text { (mm) }\end{array}$ \\
\hline 1 & April, 2016 & 21 \\
\hline 2 & December, 2016 & 21 \\
\hline 3 & December, 2016 & 23 \\
\hline
\end{tabular}

${ }^{*} 50 \mu \mathrm{l}$ of $40 \% \mathrm{w} / \mathrm{v}$ aqueous Garlic extract loaded per well 
bioRxiv preprint doi: https://doi.org/10.1101/162214; this version posted July 29, 2018. The copyright holder for this preprint (which was not A certified by peer review) is the author/funder, who has granted bioRxiv a license to d 3 lay the preprint in perpetuity. It is made available under
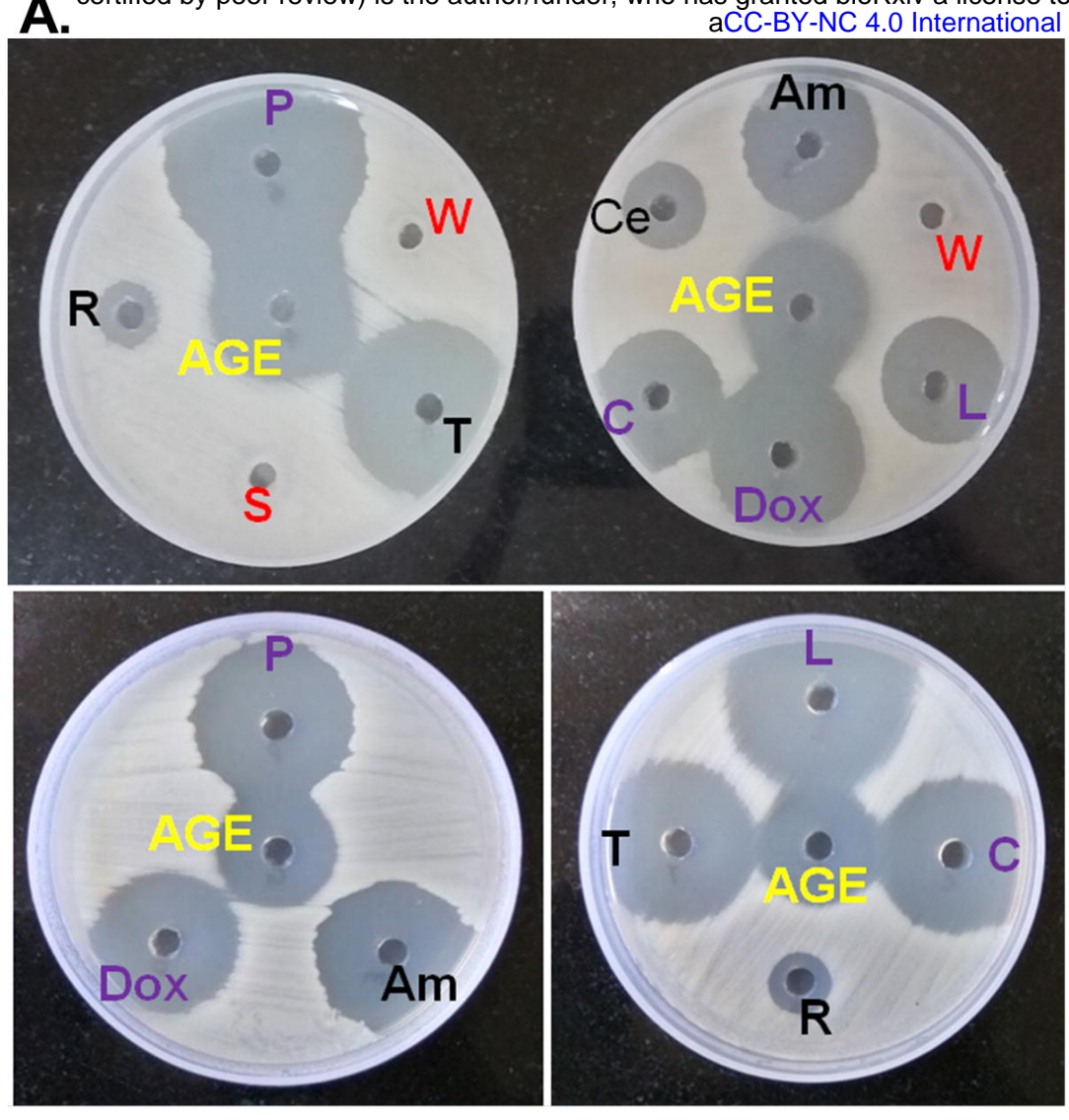

\begin{tabular}{|l|c|c|}
\hline $\begin{array}{l}\text { Antibiotics } \\
\text { (FDA Approved) }\end{array}$ & $\begin{array}{l}\text { Anti- } \\
\text { Bacillus } \\
\text { anthracis } \\
\text { Activity }\end{array}$ & $\begin{array}{l}\text { AGE } \\
\text { Antagonist } \\
\text { ic activity }\end{array}$ \\
\hline Amoxicillin (Am) & + & - \\
\hline Cefixime (Ce) & + & - \\
\hline Ciprofloxacin (C) & + & - \\
\hline Doxycycline (Dox) & + & - \\
\hline Levofloxacin (L) & + & - \\
\hline Penicillin (P) & + & - \\
\hline Rifampicin (R) & + & - \\
\hline $\begin{array}{l}\text { Sulfamethoxazole } \\
\text { (S) }\end{array}$ & - & - \\
\hline Tetracycline (T) & + & - \\
\hline $\begin{array}{l}\text { Aqueous Garlic } \\
\text { extract (AGE) }\end{array}$ & + & \\
\hline
\end{tabular}

\section{W: Water/Solvent control}

*Sulfamethoxazole, a Folic acid biosynthesis inhibitor, is known to not inhibit Bacillus anthracis growth

C.

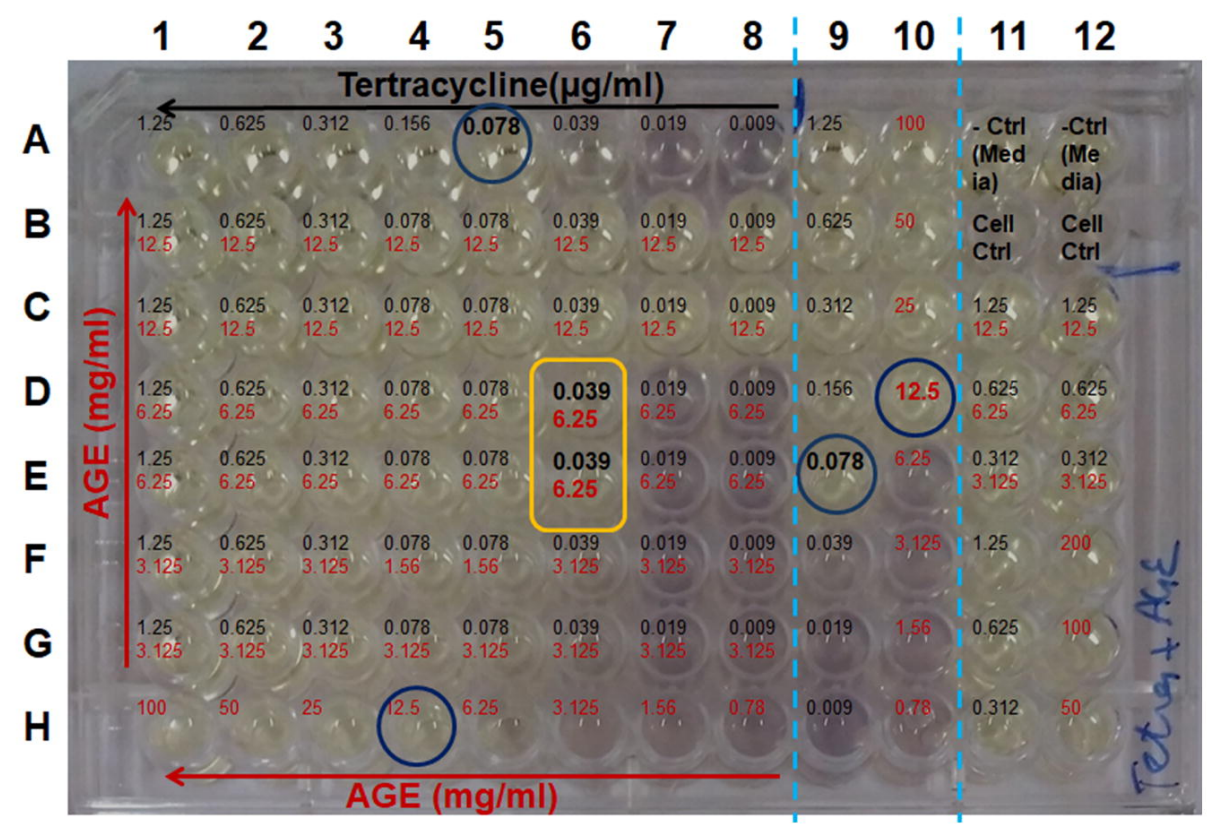

D.

\section{FICI Value for tested Antibiotics and AGE combination}

\begin{tabular}{|l|l|l|}
\hline Antibiotic & $\begin{array}{l}\sum \text { FICI } \\
\text { value }\end{array}$ & Effect \\
\hline Penicillin & $0.5-0.8$ & Synergistic effect \\
\hline Tetracycline & $0.7-1.0$ & Synergistic effect \\
\hline Rifampicin & $0.5-0.8$ & Synergistic effect \\
\hline Amoxicillin & $1.0-2.0$ & No effect \\
\hline Ciprofloxacin & $1.0-2.0$ & No effect \\
\hline Doxycycline & $1.0-2.0$ & No effect \\
\hline Levofloxacin & $1.0-2.0$ & No effect \\
\hline
\end{tabular}

Effect categorized- strongly synergistic, $\mathrm{FICl}$ $<0.5$; synergistic, $\mathrm{FICl}<1$; additive, $\mathrm{FICl}=1$; no effect, $1<\mathrm{FICl}<2$; antagonistic, $\mathrm{FICl}>2$. 